\title{
Recycled aggregate concretes - a state-of-the-art from the microstructure to the structural performance
}

\author{
Hoai-Bao Le ${ }^{1,2}$, Quoc-Bao Bui ${ }^{1, *}$ \\ ${ }^{1}$ Sustainable Developments in Civil Engineering Research Group, Faculty of Civil \\ Engineering, Ton Duc Thang University, Ho Chi Minh City, Vietnam. \\ ${ }^{2}$ Mien Tay Construction University, Vinh Long, Vietnam \\ *Corresponding author: buiquocbao@tdtu.edu.vn
}

\begin{abstract}
In the context of a circular economy, the recycling becomes more than more important. In the construction industry, the wastes from the destructions of old structures are significant. The recycling of the old concretes can contribute to reduce the extraction of the new natural resources (gravel, sand) and to reduce the waste deposit areas. Numerous studies have already been performed to investigate different aspects of recycled aggregate concretes (RAC). Several publications have also done the detailed reviews on certain topics of RAC (such as mechanical properties, mix proportioning); however, still few articles have done the global synthesis on different aspects of RAC. This paper presents a rapid state-of-the-art of numerous topics related to RAC: from the recycling techniques of old-concrete-aggregates, the mix proportioning, the mechanical properties, the durability, the structural behavior and the fire resistance. The number of existing studies synthesized is relatively important (about 170 publications). The aim of the present paper is to provide a rapid overview about existing scientific investigations on RAC, which can offer a good guidance to researchers and engineers who are entering to this area.
\end{abstract}

Keywords: recycled aggregate concrete (RAC); mechanical properties; reinforced $R A C$ columns; reinforced RAC beams; durability; fire resistance.

\section{Introduction}

Until now, the demolished concrete is usually destinated for the construction of the roads. However, the necessity to incorporate the recycled aggregates in other applications is rising because in numerous countries, the number of buildings which have been constructed in the 1950s and 1960s is high (especially in Europe, after the $2^{\text {nd }}$ Word War) which will touch the end of their life; the destruction of these buildings are likely probable because the demand about the energy performance in the actual norms increased, but the energetic renovation on these old buildings are complicated. Furthermore, in developed countries and in many developing countries, there are less than less new roads to be constructed, so the use of recycled aggregates in the roads will be reduced. Another reason is that other materials or wastes (such as natural aggregates of low quality, mix of construction wastes, non-toxic wastes, ...) which have less quality than recycled aggregates from old concretes can also be used for the road sub-layers; so the recycled aggregates from the old concretes which have better quality than such wasted materials, should be used for structural applications [1]. The recycling of destructed concretes can on one hand, reduce the exploitation of new natural resources, and on the other hand, reduce the waste deposit areas, which become an environmental, economic and societal problem [2], [3].

The recycling old-concrete to produce recycled aggregates and use them to manufacture new concretes (called "recycled aggregate concrete" - RAC) is an approach which has already been investigated since numerous years. However, one of the most important points which slows down the development of this approach in practice is the cost. Until now, when the natural 
resources for concrete manufacturing (gravel, sand) is still available for the most of countries on the world, the use of RAC has not yet presented considerable economic advantages. Nevertheless, in the new context of a circular economy, where the environmental aspect is highlighted, the exploitation of natural resources and generate wastes must be reduced, RAC takes more than more place in the construction industry [1]. The number of studies existing in literature on the topic of RAC is high. There have been already several interesting review papers or books on this topic [1], [4]-[7]; these publications presented carefully in details for one or several aspects relative to RAC. The aim of the present paper is to propose a global synthesis on different aspects relative to RAC: from the recycling techniques of old-concrete-aggregates, the mix proportioning, the mechanical properties, the durability, the structural behavior and the fire resistance. For each aspect, only the fused results obtained from different studies is presented, which enables to the readers to rapidly have a global overview about RAC. It is worth noting that this synthesis work is not easy because the results obtained in each study depend to numerous parameters such as: type and quality of parent-old-concrete, recycling method, replacement ratios of recycle aggregates, strategy for the mix proportioning (considering the water absorption by the recycled aggregates or not), type and amount of binder used, using admixture or not,... So, for further detailed information, the readers can refer to the cited references.

\section{Aggregates obtained from the recycling}

The wastes of constructions and demolitions are divided into two categories: dangerous and non-dangerous wastes. The dangerous wastes are such as asbestos or old concretes from the nuclear plants. The current investigations concentrate on non-dangerous wastes [8].

\subsection{Main techniques of demolition}

Different techniques of demolition exist, but there are three most current ones. The first technique is the demolition with hand tools such as hammer, mallet, pickaxe which can be electric, pneumatic or hydraulic [9], [10]; this technique is used for small volumes, or in the preparation phases of demolition (for example remove the dangerous elements such as asbestos, plomb, ...); this technique is slow and expensive, but enables a better sorting than other techniques.

The second current technique is the demolition with mechanical engines, such as balls, pliers, cutters. For high-rise buildings, mini-engines can also be used to destruct the highest stories first, and then other larger engines demolish the structure from the ground.

The third technique is the use of blasting, which is a robust technique. This technique is applied when the above classical techniques are not applicable in reason of the building size or the risk, or the low-efficacity of other techniques. This technique is rapid but the sorting of wastes after the demolition is more complex than other techniques.

\subsection{Main techniques of recycling}

There are different techniques for the recycling of wastes from construction and demolition, but the current processes generally compose of the following operations [11]:

- Elimination of light elements (plaster, wood, plastic etc.) by the sorting systems (manual/pneumatic/hydraulic separators)

- Extraction of metal elements by using the magnetic separators

- Crushing, screening to produce compatible desirable materials

- Flocculation of clays, for example by floatation technique. 
A typical recycling platform of recycled aggregates for RAC is following [12]: at the entrance, the wastes are visually inspected, sorted by hydraulic excavators and then stocked. The large concrete blocks are reduced by appropriate equipment such as hydraulic clamps; the material is then crushed. The metal elements are retired by a magnetic separator. Finally, the material is screened in several times to obtain the desirable sizes of aggregates. Some practice platforms may apply simpler processing, however several publications proposed different more complex techniques to improve the recycling process, which can be cited: aeraulic sorting for contaminants such as paper, plastic, wood [13], [14]; rotative sieving for large blocks and large size contaminants [15], [16]; until three steps of crushing [17]; compressed air for the dust liberation [18]; washing for dust liberation [19]; water jig [20], [21]; air jig [22]; sorting by sensors [14][23]; systems for separation of mortar from recycled aggregates [24]; magnetic separation of mortar and clay bricks [25], [26]; manual separation on the treatment carpet to eliminate the grand size impurities after the first crushing [27]. The thermal treatment was also investigated, however this technique is only efficient for temperature from $600^{\circ} \mathrm{C}$, which can cause damages for aggregates treated [21].

The recycled aggregate is usually a mix of natural aggregate, hardened cement paste which is generally bonded to natural aggregate. Therefore, the properties of the recycled aggregate depend on the properties of these two components and their proportion in the original concrete. The recycled aggregate's porosity is generally higher than that of natural aggregate, which changes significantly the characteristics of recycled aggregates when compared to natural aggregate. Indeed, the recycled aggregates have a higher water absorption and a lower specific density than natural aggregates. The chemical composition of the combination of natural aggregate and hardened cement paste bonded may cause later some pathologies for the RAC, such as the alkali-silice reaction [28].

After the crushing, numerous hardened cement paste fall into the fine aggregate fraction which causes the important heterogeneities in the fine recycled aggregate and increases the water adsorption of the fine fraction (recycled sand). The water absorption of fine recycle aggregate is about 6-9\% while for natural sand, this value is only about $0.5-2 \%$ [28]. Due to the low quality of the recycled fine aggregate, it is not recommended to replace totally natural sand by recycled fine aggregate; several authors proposed to mix the natural sand with the recycled fine aggregate which has a proportion less than 30\% [28], [29].

\section{Applications of recycled fine aggregates}

The recycled fine aggregate obtained is about $50 \%$ after the crushing of concrete recycled, however as mentioned in the previous section, the use of recycled fine aggregate directly in a new concrete is limited, due to its low quality. That is why other alternative ways should be found to use the recycled fine aggregate. Three main solutions are found in the practice:

- Recycled fine aggregate is used as alternative raw material in fabrication of Porland clinker. It was shown that the recycled sand principally constitutes of quartz and calcite, with a minor presence of feldspars and mica [30]. The experimental tests from this study also showed that the recycled sand could be an alternative raw material to produce clinker, with a maximum substitution ratio of $25 \%$ (in mass) and an optimum substitution ratio of $15 \%$. The obtained clinker had very similar mineral and chemical characteristics to that of the reference clinker.

- Recycled fine aggregate is used as a complementary material in the fabrication of Porland cement (other than clinker). Recycled fine aggregate can be used to successfully replace the limestone fillers in the fabrication of cement [31]. 
- Recycled fine aggregate is grinded and used as a filler in concrete. The results in Cyr et al. (2018) [31] showed that the recycled fine aggregate behaved as inert charge or with very low pozzolanic effects (due to the presence of elements from the hardened cement paste). When compared to two above options for the use of recycled fine aggregate, this third option is generally less interesting. However, for each context, an economical study should be done to choose the best solution among these three options.

\section{Recycled aggregate concretes (RAC)}

\subsection{Pre-treatment of recycled aggregates and mixing processing}

One of the difficulties in the application of recycled aggregate concrete in practice is the control of recycled aggregate's water content. A high water absorption and heterogeneity of recycled aggregate causes difficulties to determine the accurate water from the formulas [32], [33]. Moreover, the water absorption, between the end of mixing and the casting on site, can modify the concrete workability during the transport. Indeed, it was shown that recycled aggregates could absorb between 100 seconds and $1 \mathrm{~h}$ until $5 \%$ of water of the mixture [34]. To avoid variation of concrete consistency, several studies proposed to immerse recycled aggregates in water during 10 minutes to obtain a complete saturation state [35], [36], which enables to avoid the water transfer into the recycled aggregates. Effects of the pre-saturation on the recycled coarse aggregate were diverse in different studies; it was noted in several studies that the pre-saturation had few importance on the slump values [37]. Kadri et al. (2018) [38] observed that the concrete having admixture (superplasticizer or retarder) had better fluidity when the recycled aggregates were pre-saturated. The pre-saturation is primordial for the case of recycled fine aggregate which enables to reduce several risks of cracking [39].

It is worth noting that the pre-humidification of recycled aggregates, by fixing a constant water amount added, increases the concrete workability but decreases the concrete compressive strength [40], [41]. However, Kurowa et al. (1999) [42] showed that the water absorbed by the recycled aggregates, before or during the mixing, could improve the concrete strength. From these results, the Two-Stage Mixing Approach (TSMA) was proposed: 50\% of total water was introduced first to the aggregates, then the cement was introduced. This two-stage mixing approach enables to increase about $15 \%$ of the compressive strength, about $20-25 \%$ of the tensile strength, and also the durability of concrete (penetration of chloride ions and carbonation) when compared to one-stage mixing. The positive effect is explained by an improvement of the new interfacial transition zone around the recycled aggregate grains [43], [44]. This two-stage mixing approach could limit several negative aspects for concretes using recycled fine aggregates [45]. Brand et al. (2015) [46] tested the performance of TSMA on three types of recycled aggregates: oven-dried, partially saturated and completely-saturated; the results showed that partially-saturated was the most adapted for TSMA.

Other mixing procedures were also tested. Liu et al (2016) [47] mixed firstly the cement paste, then incorporate the sand and the gravels, to envelop the aggregates by cement paste; this technique had an intermediary effect on the mechanical properties, between the normal mixing and two-stage mixing approach. Liang et al. (2015) [48] investigated the Sand Enveloped Mixing Approach (SEMA), by mixing first the natural sand, cement and $3 / 4$ total water, then the aggregate coarse aggregates were added; this technique enabled to mix easily the sand with cement and water, before that recycled coarse aggregates absorbed water. The results with sand enveloped mixing technique were better than that with two-stage mixing.

The process to envelop the recycled aggregates with cement grout in TSMA improved the compressive strength of concrete, that was why some other treatment techniques were tested. It was observed that immersing recycled aggregates in a pozzolanic liquid could increase the concrete compressive strength, but this technique had also a negative effect on the workability 
of fresh concrete [42]. Other studies combined the use of mineral additives with the mixing processing, for example the addition of fly ash or slag have the positive effects on the compressive strength and the penetration of chloride ions when the three-stage mixing

\subsection{Effects of recycled aggregates on early-age RAC}

The recycled aggregates have specific properties due to the presence of the old cement paste, porous mortar, impurities such as plaster, gypsum. When compared to natural aggregates, the recycled aggregates are lighter, more angular, lower compacity; more porous, more brittle, a higher water absorption; potentially reducing efficacity of superplasticizer due to the interaction with sulfates and impurities. That is why influences of the recycled aggregates on the behaviour of concrete at early age are important to be investigated. However, there are less studies on the behavior of RAC at early-age (especially at plastic state) than at hardened state.

One of the important phenomena of the early-age concrete is the cracking. There are different reasons which can generate the early-age cracking, but the main following reasons can be listed. The first reason is related to the water evaporation, at very early time after the casting [52]. The water layers around the particles disappears progressively with the evaporation; the water meniscuses are formed between the particles which create the bonding between the particles which is a weak force from the capillarity pressure, because at the very early state, other bonding forces (such as covalent force in the cement matrix) have not yet been developed. As this capillarity force is weak, it is unstable and the air can start to penetrate in the pores, creating some "local drilling" of the capillarity pressure. When the air starts to fill the big pores, there is a rearrangement of the particles due to the capillarity pressure - equivalent to a decrease of the volume [53]. When the volume diminution is not equal to the volume of water evaporated, the cracking appears. Therefore, the air penetration is correlated to the cracking [54]. The second phenomenon play the role on the early-age-cracking is the plastic shrinkage. The elastic modulus of concrete increases rapidly during the early-age while the tensile strength increases slowly, which reduces the capacity of deformation [55]. The cracking starts when the tensile stresses exceed the tensile strength [56]. The recycled aggregates are well known as promote the shrinkage and creep of concrete, reduce the compressive strength and the elastic modulus (with a given binder). That is why it is not easy to predict the cracking for recycled aggregate concrete.

Roziere et al. (2018) [57]tested two sequences of curing: the first one is a "moderate curing" with $50 \% \mathrm{RH}$ and the wind velocity less than $0.3 \mathrm{~m} / \mathrm{s}$; the second one is a "severe curing" with $45 \% \mathrm{RH}$ and $8 \mathrm{~m} / \mathrm{s}$ of wind velocity. The results showed that due to a relatively high porosity, recycled aggregates absorbed the water which could be released to the cement paste during the curing. With the moderate curing, the plastic shrinkage could be reduced, thanks to the "internal curing" with water released from recycled aggregates [58]. However, under the severe curing, the high evaporation increased the shrinkage. It was also observed that the initial saturation 
ratio had a low influence when the total water (water existing in the recycled aggregates + water added) was constant. That is why a suitable curing is recommended.

\subsection{Microstructure of hardened RAC}

The recycled aggregates are composed of natural aggregates covered by cement paste (or hardened mortar). The presence of these old carbonated and porous pastes can modify the formation of the interfacial transition zones between the aggregates and the cement matrix. To understand these mechanisms, several studies have been performed to investigate the microstructure of hardened RAC [59],[60]. The interfacial transition zone is located at the interface between the aggregate and the cement paste [61], [62]. In this zone, a gradient of porosity is observed: the porosity increases from the cement paste to the aggregate surface. The reason of this microstructure is that: at the boundary of the aggregates, in the cement paste, the water content increases and so the cement content decreases. The initial thickness of this zone is several dozens of microns. During the curing, the porosity decreases because the hydration products are created, so the thickness of the interfacial transition zone decreases also. During this period, there is the transfers of hydrated product (mainly Porlandites) between the rich cement zones and poor cement zones.

With porous aggregates (such as recycled aggregates) which have a high water absorption, the mechanisms for the formation of interfacial transition zones are strongly influenced by the water exchanges between the aggregates and the fresh cement paste. For light aggregates having macropore networks (from several hundreds of micron to several millimeters), an initial dry state of aggregates causes an absorption of water during the mixing and casting, this water absorption leads to a more compact and more "bonding" interfacial transition zone [59], [60], [63], [64]. For non-porous aggregates, the similar porosities were observed for oversaturated aggregates and dry aggregates; however, for the interfacial transition zones between the old cement and the new one, an improvement was observed when the humid aggregates were used [65].

Garcia-Diaz et al. (2018) [66] investigated also the interfacial transition zones for RAC, but for normal concretes (grades from $\mathrm{C} 25$ to $\mathrm{C} 35$ ) and higher strength concrete (C45). The results confirmed that the interfacial transition zones obtained for humid aggregates were more porous that that of dry aggregates, due to the release of water from the humid aggregates. However, for higher strength concrete, where the water/cement ratio was decreased, the water released from the humid aggregates participated to the hydration of cement (like a "internal curing") which could reduce also the porosity of the interfacial transition zone.

\subsection{Mechanical properties of RAC}

\subsubsection{Compressive strength}

The most important parameter characterising a concrete is its compressive strength. Numerous studies in the literature investigated about influences of the recycled aggregates on the compressive strength of RAC. Silva et al. (2014) [67] mentioned 236 articles on the topic of RAC, among which there were 119 articles investigating on the compressive strength. It was difficult to have the univocal conclusions, due to different reasons: First, RAC is usually compared to reference concretes using natural aggregates, but the quality of natural aggregates strongly influenced the conclusions because the same recycled aggregate can have different impacts if the natural aggregate substituted possesses excellent or poor mechanical properties. Second, different strategies were adopted to compare the RAC with different substitution ratios: 
the same total water/cement ratio, or the same effective water/ cement ratio, or the same workability which cause the different effective water/ cement ratio. Finally, the conclusions depend also on the characteristics of recycled aggregates used: form, size, mechanical properties etc.

From 119 articles published in the literature, Silva et al. (2014) [67] performed a statistic study and proposed a classification of recycled aggregates in function of the water absorption and the dry density (Figure 1). The recycled coarse aggregates are usually located in the zones A and $\mathrm{B}$, while the recycled fine aggregates are usually located in the zones $\mathrm{C}$ and $\mathrm{D}$, due to their higher content of cement paste. Then, the authors proposed also a very interesting figure which was a synthesis about relationship between the relative compressive strength and the replacement level of recycled aggregates (Figure 2). This figure shows a general trend when the replacement level of recycled aggregate increases, the compressive strength decreases, for a same water/cement ratio. This diminution can be amplified if the same cement amount or the same workability is demanded, because the use of recycled aggregates generally increases the necessary water. The decrease of compressive strength is explained also because the general mechanical properties of recycled aggregates are lower than that of natural aggregates. Indeed, the natural aggregates are generally obtained from the rocks having compressive strength higher than $50 \mathrm{MPa}$, while the recycled aggregates are obtained by the crushing of concretes which have compressive strength lower than 50MPa. Therefore, for a same replacement level, if the recycled aggregates are obtained from a high performance concrete, no significant difference is observed when compared to the natural aggregates [68]. The figure confirms that the recycled fine aggregates have lower mechanical qualities than the recycled coarse aggregates, so the recycled fine aggregates reduced the compressive strength of RAC.

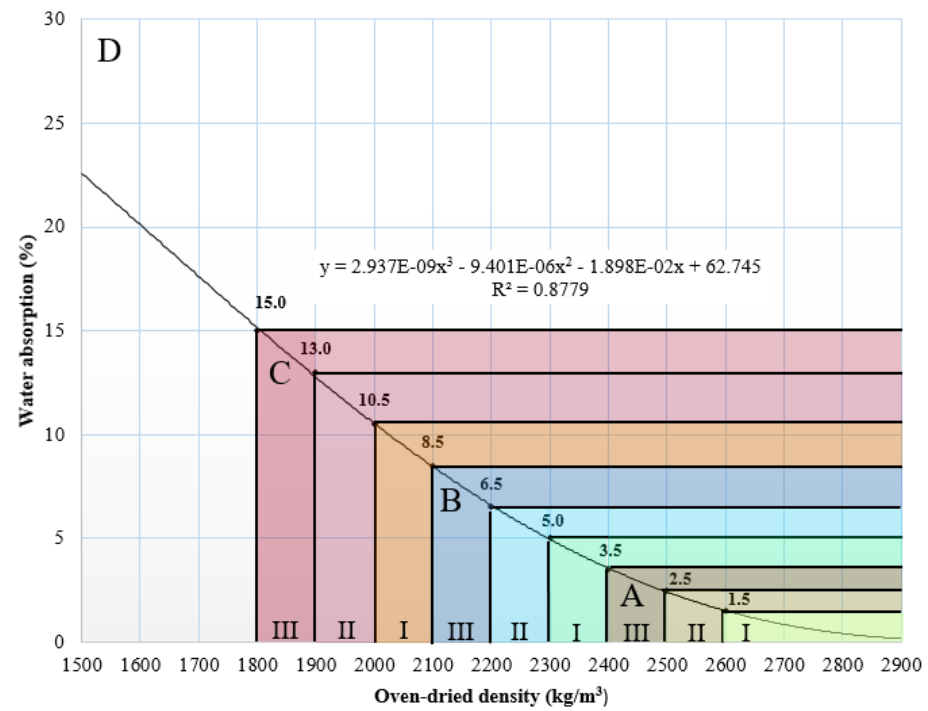

Figure 1. Classification of aggregates based on the water absorption and the oven-dried density [67] 


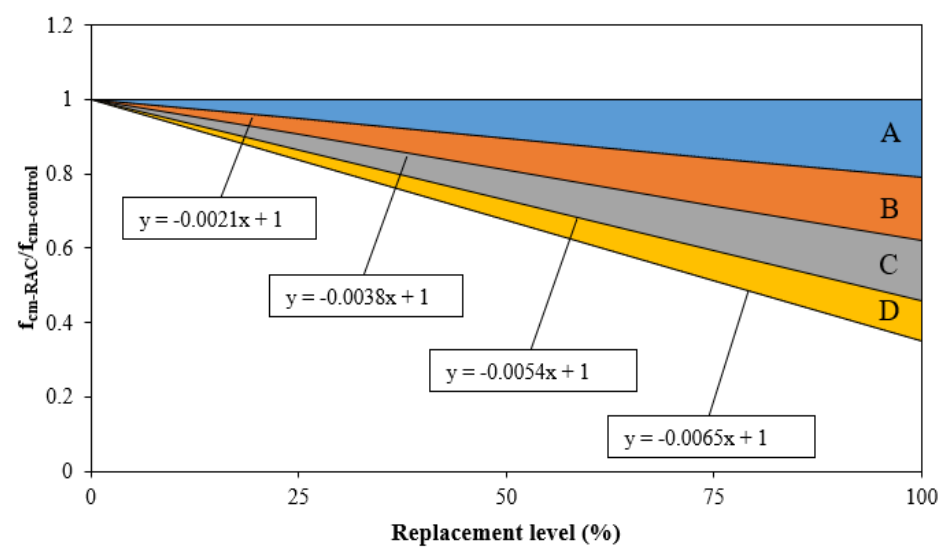

Figure 2. Statistic result on the influence of replacement level of recycled aggregates on the relative compressive strength, for a same effective water/cement ratio; $f_{c m \text {-control }}$ is the mean compressive strength of referent concrete which uses natural aggregates; $f_{c m-R A C}$ is the mean compressive strength of RAC [67].

Although the figures above are very interesting, they are only the results of a statistic study, the models with more scientific considerations about different parameters are still necessary for the mix proportioning. Several studies proposed different approaches for the mix design and the prediction of compressive strength for RAC [69]-[75]. Among these studies, the model proposed by De Larrard (1999)[75] which is a modified version of the classical Feret's model for ordinary concrete had been adopted for RAC and showed its robustness, for the accuracy, the simplicity and the scientific significance [74], [76], [77]. In this model, the mean compressive strength of concrete $f_{c m}$ is determined by:

$$
f_{c m}=K_{g} \cdot R_{c 28 \cdot}\left[V_{C} /\left(V_{C}+V_{W}+0.5 V_{A}\right)\right]^{2} \cdot E M P^{-0.13}
$$

where

- $R_{c 28}$ is the characteristic compressive strength of cement paste at 28 days old.

- $\quad V_{C}, V_{W}$ and $V_{A}$ are the volume of cement, water and air, respectively. The volume of air in the current concretes is about $1-3 \%$ of the total volume.

- EMP is the maximum thickness of the paste (distance between two big gravels), which is calculated by:

$$
E M P=D_{\max }(g * / g)^{1 / 3}-1
$$

- $D_{\max }$ is the maximum diameter of aggregates, defined as diameter of $90 \%$ passing.

- $g *$ is the compacity of the aggregate skeleton, which can be determined by the ratio of the dry density of aggregate skeleton on the solid density.

- $g$ is the ratio of volume of aggregate skeleton on volume of concrete,

- $K_{g}$ is the aggregate coefficient which depend on the mechanical properties of aggregates, following their proper strength and the quality of the bonding between aggregates and cement paste. $K_{g}$ can be separately calculated for different aggregates in the mix (natural aggregates, recycled aggregates, fine aggregates, coarse aggregates):

$$
K_{g}=\Sigma\left(V F_{j .} K_{g, j}\right)
$$

Where $V F_{j}$ is the volumic fraction of the aggregate $j$ considered; $K_{g, j}$ is the aggregate coefficient of the aggregate $j$ considered 
Following Dao et al. (2014) [78], the aggregate coefficient of recycled sand can be approximately estimated by a constant value $K_{g, s}=4.42$; the aggregate coefficient of recycled gravel can be estimated by the formula:

$$
K_{g, g}=-0.0952 M D E+8.3927
$$

Where $M D E$ is the micro-Deval coefficient which specifies the attrition properties of aggregate, can be determined following micro-Deval test (NF EN 1097-1 [79]). gravels (4/10 and 6/20) is 5.767; for recycled gravels (4/10 and 10/20) is 5.173.

This approach is very interesting, not only because it separates the influence of the aggregates, the cement strength, the water/cement ratio, but also because one can easily estimate the compressive strength of RAC when know the compressive strength of the reference concrete (using natural aggregates). Indeed, by assuming that EMP is the same for RAC and reference concrete [76], from the de Larrard's formula, the ratio of $K_{\text {g-recycled aggregate }} / K_{g \text {-natural aggregate }}$ is also the ratio of $f_{c m-R A C} / f_{c m-c o n t r o l}$, which is in the intervals of [0.46-0.62], [0.62-0.79] and [0.791] for the aggregates of classes C, B and A, respectively, so one re-obtains the values in Figure 2 .

\subsubsection{Tensile strength}

Several studies showed that the tensile strength of RAC decreased when the substitution level (of natural aggregates by recycled aggregate) increased. This diminution could reach $13 \%$ in function of the substitution level [80], [81].

A formula to obtain the tensile strength $f_{c t m}$ from the compressive strength $f_{c m}$ was proposed by de Larrard (1999) [75] and have been validated by numerous studies which showed the good accuracy of this formula [76], [80]:

$$
f_{c t m}=k_{t} \cdot f_{c m}^{0.57}
$$

where $k_{t}$ is the coefficient which is determined by:

$$
k_{t}=\Sigma\left(V F_{j .} k_{t, j}\right)
$$

Several studies [67], [82] showed that the above relationship between the tensile strength and the compressive strength is independent to the replacement level of recycled aggregates.

The values of $k_{t, j}$ presented in Ghorbel et al. (2018) [76], Ajdukiewicz \& Kliszczewicz (2007) [80], were of 0.373-0.471 for natural aggregates (in function of the type of aggregate where higher quality provides higher value of $k_{t}$ ) and $0.312-0.446$ for recycled aggregate, respectively. So the values of $k_{t}$ can vary case by case, however, for the studies cited, the value of $k_{t}$ for recycled aggregate was generally $7-13 \%$ less than that of the corresponding natural aggregate.

To avoid characterizing the values of $k_{t}$, other empirical formulas were also proposed for the simplified relationship between the tensile strength of RAC and its compressive strength. Ghorbel et al. (2018) [76] did a comparative study to verify the performance of these formula, then these authors have proposed a modified version of Omary et al. (2016) [83] formula to obtain the most suitable formula:

$$
f_{c t m}=0.364\left(1-\alpha_{f c t m} \Gamma_{m}\right)\left(f_{c m}\right)^{0.608}
$$

Where $\alpha_{f c t m}=0.142 ; \Gamma_{m}$ is the replacement level (in mass), which is the ratio (in mass) between the recycled aggregates on the total aggregates (natural aggregates + recycled aggregates). 
As mentioned earlier, the recycled aggregates contain the cement paste and therefore their elastic modulus is generally less than that of natural aggregates. That is why the elastic modulus of RAC is generally less than that of ordinary concrete.

De Larrard (1999) [75] proposed a tri-spheres based model for the determination of elastic modulus of ordinary concrete which could be adapted for RAC [76]. The mean elastic modulus of concret $E_{c m}$ is determined by:

$$
E_{c m}=\left\{1+2 g\left(E_{g}{ }^{2}-E_{m}{ }^{2}\right) /\left[(g-g *) E_{g}^{2}+2(2-g *) E_{g} \cdot E_{m}+\left(g+g^{*}\right) E_{m}{ }^{2}\right\} E_{m}\right.
$$

where

- $\quad g *$ is the compacity of the aggregate skeleton, which can be determined by the ratio of the dry density of aggregate skeleton on the solid density.

- $g$ is the ratio of volume of aggregate skeleton on volume of concrete,

- $E_{m}$ is the elastic modulus of cement paste, which can be estimated from the compressive strength of cement: $E_{m}=226 R_{c}$

- $\quad E_{g}$ is the elastic modulus of the aggregate skeleton; $E_{g}$ can be separately calculated for different aggregates in the mix:

$$
E_{g}=\Sigma\left(V F_{j} \cdot E_{g, j}\right)
$$

Where $V F_{j}$ is the volumic fraction of the aggregate $j$ considered; $E_{g, j}$ is the elastic modulus of the aggregate $j$ considered

For recycled aggregates, Dao et al. (2014) [78] noted that the elastic modulus of recycled fine aggregates and recycled coarse aggregates was close (the difference less than $7 \%$ ) and proposed a formula to calculate the elastic modulus of recycle aggregates $\left(E_{g, R A}\right)$ from that of the source concrete $\left(E_{s}\right)$ and that of the source gravels $\left(E_{g s}\right)$ :

$$
E_{g, R A}=0.65 E_{s}+0.35 E_{g s}
$$

The usual values obtained for $E_{g, R A}$ were of 35-60 GPa, which is less than the most of natural aggregates. This observation explains why when the replacement level increases, the elastic modulus of concrete decreases.

The above model is interesting and provide high accuracies, however, for the structure design, simpler formulas should be proposed for a rapid calculation (with an acceptable higher error). Numerous empirical formulas were proposed by simplifying the relationship between the elastic modulus and the compressive strength, but most of them are for ordinary concrete. Ghorbel et al. (2018) [76] verified the validity of these existing formulas by using the data with 441 values obtained by the authors and from the literature. The authors showed that the existing formulas proposed for ordinary concretes were not suitable for RAC; they proposed a modification to take into account the recycled aggregates and showed that the modified version of the Wardeh et al. (2015) [84] formula was the most suitable:

$$
E_{c}=17553\left(1-\alpha_{E c} \Gamma_{m}\right)\left(f_{c m} / 10\right)^{0.42}
$$

Where $\alpha_{E c}=0.131$

$\Gamma_{m}$ is the mass replacement level, which is the mass ratio between the recycled aggregates on the total aggregates (natural aggregates + recycled aggregates).

\subsubsection{Evolution of compressive strength following the time}


The results from Omary et al. (2016) [83] shows that evolution of the compressive strength is independent on the replacement level and the formula proposed in Eurocode 2 for ordinary concretes can also be applied for RAC:

$$
\begin{gathered}
f_{c m}(t) / f_{c m}(28 \text { days })=\beta_{c c}(t) \\
\beta_{c c}(t)=\exp \left\{s\left[1-(28 / t)^{1 / 2}\right\}\right.
\end{gathered}
$$

where $s$ is a coefficient depending to cement type, for example for CEM II, $s=0.2$.

The peak strain $\varepsilon_{c l}$ is the strain corresponding to the maximum stress in uniaxial compression. Numerous studies showed that when the replacement level increases, the peak strain increases [83]-[88].

The ultimate strain $\varepsilon_{c u}$ is the strain determined at the post-peak side, corresponding to the stress equal to 0.6 of the maximum stress. When the replacement level increases, the ultimate strain increases also [83].

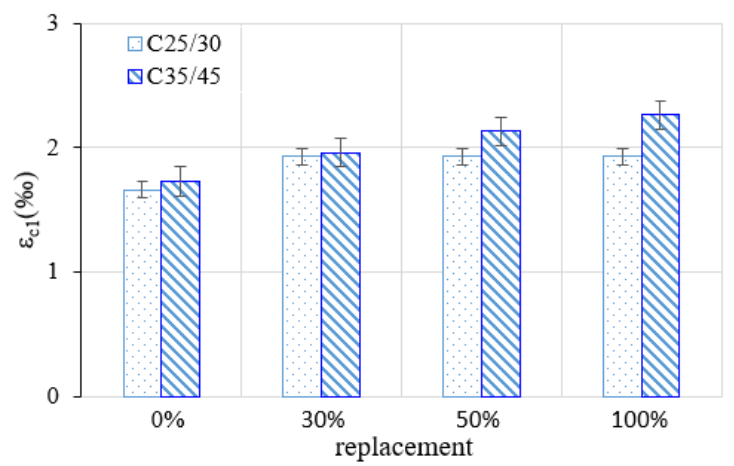

(a)

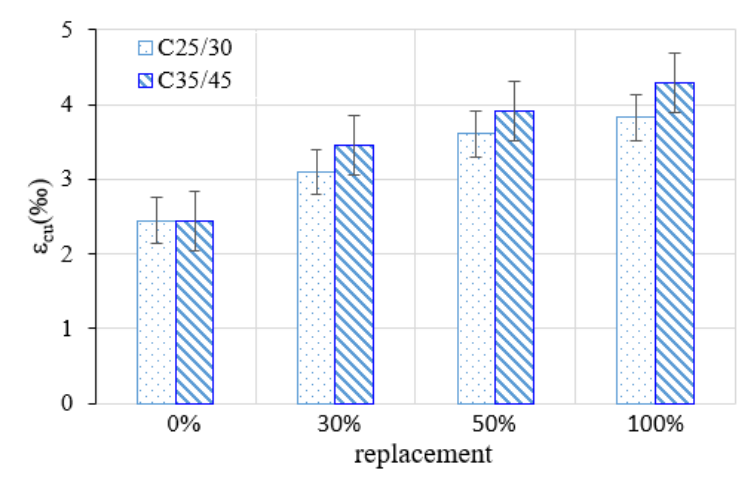

(b)

Figure 3. Influence of the replacement level on the peak strain $\varepsilon_{c 1}$ (a) and ultimate strain $\varepsilon_{c u}$ (b) [76].

After a comparative study on different existing formula, Ghorbel et al. (2018) observed that the formula proposed by Wardeh et al. (2015)[84] was the most suitable to predict the peak strain:

$$
\varepsilon_{c l}=1.1\left(f_{c m}\right)^{0.175}
$$

For the ultimate strain, a formula was also proposed for concrete having characteristic compressive strength $\mathrm{f}_{\mathrm{ck}} \leq 50 \mathrm{MPa}$, which is a normal grade:

$$
\varepsilon_{c u}=\left\{0.00298-0.0625\left[\left(50-f_{c m}\right) / 100\right]^{4}\right\}\left(1+0.2 \Gamma_{m}\right)
$$

However, the validity of this formula should be checked with more experimental data.

\subsubsection{Stress-strain relationship under uniaxial compression}

Ghorbel et al. (2018) [76] adopted the analytical expressions of stress-strain relationship for ordinary concretes under uniaxial compression and tested their relevancy for RAC (data from Omary et al. 2016 [83]). For example, following Eurocode 2 (2005)[89]:

$$
\sigma / f_{c m}=\left(k \eta-\eta^{2}\right) /[1+(k-2) \eta]
$$


where $k=E_{c} \cdot \varepsilon_{c l} / f_{c m} ; \quad \eta=\varepsilon / \varepsilon_{c l}$

457 The authors showed that the Eurocode 2 formula could reproduce the pre-peak behaviour of

458 RAC under uniaxial compression, while there was more difference for the post-peak behaviour.

459

460

461

462

463

464

465

466

467

468

469

470

471

472

473

474

475

476

477

478

479

480

481

482

483

484

485

486

487

\subsection{Shrinkage, creep, fatigue}

\subsubsection{Shrinkage:}

Influences of recycled aggregates on the long term shrinkage of RAC have been investigated in numerous studies [90]-[96]. The results showed that the replacement by recycled aggregates increased the shrinkage, from 15 to $60 \%$, in function of the replacement level: until $30 \%$ of replacement level, the shrinkage increase was limited, and less then $10 \%$ in the most of cases; however, when the replacement level is more than $50 \%$, the shrinkage increase becomes high, which can be $60 \%$ in some cases, but in general, the shrinkage increase is not more than $25 \%$ [97]. The increase of shrinkage for RAC is explained by the high water absorption of the recycled aggregates which are porous and contains the old cement paste. Brand et al. (2015) [46] investigated the shrinkage with three pre-saturation levels of recycled aggregate: saturated, partially saturated $(80 \%)$ and oven dried. The authors have observed that during the first 24 hours, the pre-saturation did not have any effect on the shrinkage; however at the long term, the RAC with pre-saturated aggregates had less shrinkage than that of RAC with oven dried aggregates.

\subsubsection{Creep:}

The recycled aggregates have also significant effects on the creep of RAC. Several studies showed that the creep increased when the replacement level of recycled aggregate increased [91], [93], [94], [98], [99]. Figure 4 presents the result of Gomez-Soberon (2002)[98] study for the creep under a permanent stress at $40 \%$ of the compressive strength. The creep of RAC having replacement ratios of recycled aggregate from $20 \%$ to $100 \%$ is higher from 35 to $51 \%$ respectively, comparing to that of natural aggregate concrete. The basic creep is not significantly affected by the recycled aggregate replacement but the drying creep is clearly affected, especially when the replacement ratio is more than $30 \%$. The results from Fan et al. (2014)[100] study showed that the characteristics of the old mortar bonded to recycled aggregates are the source of this creep increase. 


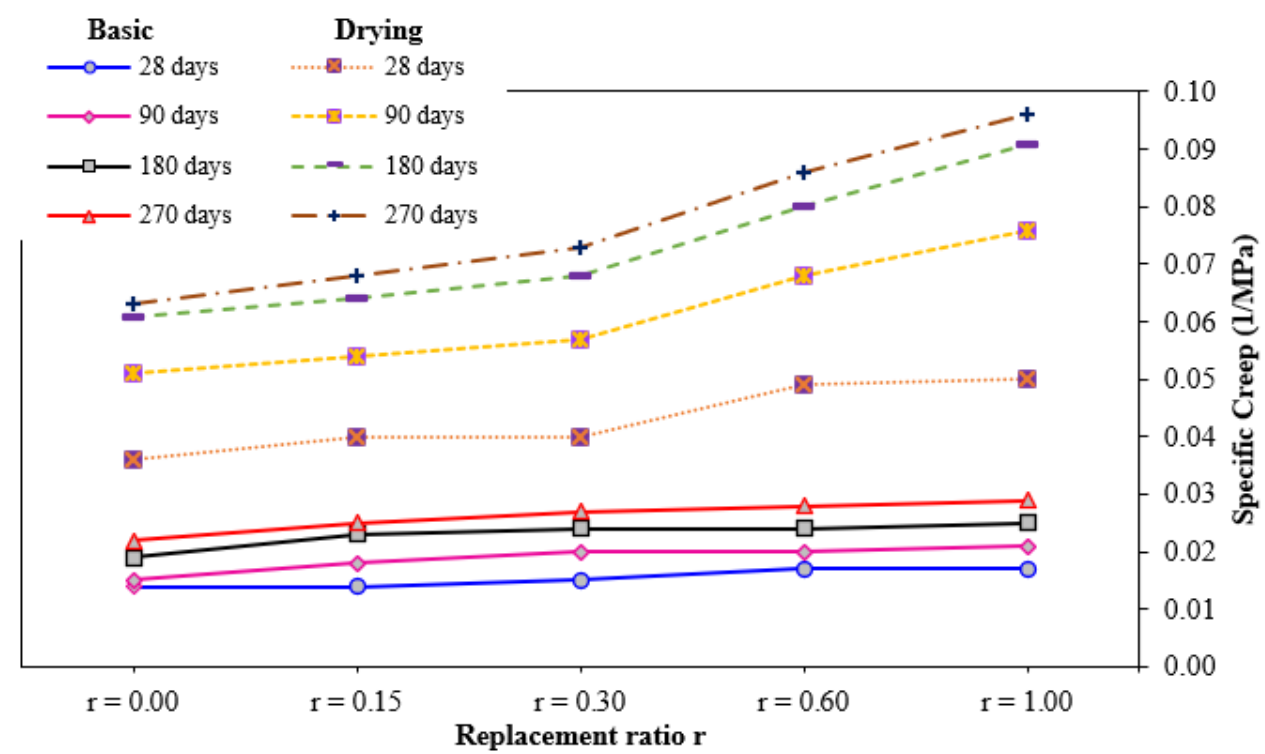

\section{Figure 4. Specific creep for different recycled concretes at different substitution ratio $r$; own creep (continuous lines) and desiccation creep (discontinuous lines). Source: Gomez-Soberon (2002) [98]}

\subsubsection{Fatigue:}

For the RAC applied for the roads, the fatigue performance is a topic to be investigated. However, this topic is less presented in the literature than other topics. The fatigue behaviour of concrete in compression, tension and bending is usually described by Arora \& Singh (2015) [101]:

$$
\sigma_{\log N} / \sigma_{0}=A+B \log N
$$

where $\sigma_{0}$ represents the static strength, $\sigma_{\log N}$ is the stress causing the failure after $N$ cycles; $\sigma_{\log N} / \sigma_{0}$ is the endurance of concrete after $N$ cycles; $A$ and $B$ are two empirical parameters, in function of loading type and concrete type, $B$ is negative.

Different results from Xiao et al. (2013) [102], Sobhan et al. (2016) [103], Arora \& Singh $(2015,2016)[101],[104]$ showed that the endurance had the trend to decrease slightly (about 5\%) and increase the standard deviation (about 5\%) when the replacement ratio increased. More data are necessary for the design of the roads, but it seems that the fatigue is not a blocking factor for the application of recycled aggregates for the road construction.

\section{Durability of RAC}

The properties related to the durability are usually the risks of steel reinforcement corrosion (carbonation, chloride penetration, air/water permeability, porosity), the resistance to thawingfreezing cycles (with and without de-icing salt), to alkali-silica reaction and the presence of sulphates (ettringite formation).

\subsection{Risks of steel reinforcement corrosion}

\subsubsection{Carbonation}


The carbonation is a well known phenomenon which induces with the time the risk of corrosion for steel reinforcement. Indeed, in atmospheric conditions, the $\mathrm{CO} 2$ percentage is about $0.4 \%$, when the $\mathrm{CO} 2$ penetrates in the cement paste, the Porlandite is consumed and the calcite is created. This phenomenon induces a decrease of $\mathrm{pH}$ in the concrete, which changes from 13 to $8-9$, so the steel reinforcement is no longer protected, then the corrosion starts when the quantity of oxygen and water is enough.

The carbonation of RAC has been well investigated in the literature [105]-[112]. The effects of the recycled aggregate incorporation on the carbonation thickness is related to different factors:

- The replacement ratio of recycled aggregates [107], [113]

- The cement amount [78]

- The characteristics of the old concrete from which the recycled aggregates are obtained [111]

- The quality of the recycled aggregates (presence of asphalt materials, bricks, glass, concrete etc.) [112]

- $\quad$ The type of crushing [96]

- $\quad$ The curing [114]

- The use of superplasticizer to reduce the Water/Cement ratio [115]

There are a heterogeneitiy in the results obtained from different studies in literature, however the following conclusions were observed [105], [110]:

- The aggregates recycled from the crushed masonries can contain different materials (light concrete, bricks, ceramics, etc) which increases the carbonation thickness.

- When the replacement ratio (of recycled aggregate) increases, the carbonation increases. The use of recycled fine aggregates increases more significantly the carbonation than the recycled coarse aggregates. Comparing to the control ordinary concrete, the ratio of carbonation thicknesses varies from 1 to 2.5 for a substitution of coarse aggregate and varies from 1 to 8.7 for a substitution of fine aggregate.

- It is possible to produce RAC having the same carbonation resistance as ordinary concrete by optimizing the Water/Binder ratio and the nature of binder.

\subsubsection{Chloride penetration}

The penetration of chloride ions, with the carbonation, is a principal cause of steel reinforcement corrosion. Numerous studies have been carried out in the literature on this topic [29], [44], [108]-[112], [117]. These studies showed that:

- The diffusion coefficient linearly increases with the replacement ratio of recycled aggregate.

- The substitution by recycled fine aggregates leads to the chloride diffusion coefficients higher than that of substitution by recycled coarse aggregates.

- Similar to ordinary concrete, the migration of chloride ions can be extenuated by reducing the water/binder ratio, or by using the blast furnace slag, the fly ash or the silica fume. 
- An improvement of the resistance to chloride ion migration was observed when the fine aggregates recycled from the bricks replaced the natural sand; the reason could probably be due to the pozzolanic nature of this material.

Certain studies proposed to use polyvinyl alcohol to improve the resistance to chloride penetration of RAC [107]. Some studies have found that the chloride diffusion coefficient of their RAC was similar to that of the ordinary concretes [117], [118]. So, a large dispersion of results between different studies is observed.

\subsubsection{Permeability}

The permeability is related to the microstructure. The permeability depends on the porosity, the connectivity of the pores, the presence of the cracks and the water content of the concrete. As the recycled aggregates are porous, and sometime cracked during the crushing, the incorporation of recycled aggregates increases the permeability [119]-[122]. However, no effect was observed for the replacement ratio of natural aggregates by recycled aggregates less than $30 \%$ [119].

The permeability can be reduced with the following parameters:

- The hardening time: the diminution of the permeability is related to the prolongation of the hydration processing. With a low water/cement ratio, a reduction of capillary voids was observed [109], [122]. Similarly, increasing the cement content reduces also the permeability [121].

- The curing condition: the curing in water reduce significantly the permeability, compared to the curing in air [115]

- The mixing processing: the two-stage mixing approach (the fine and coarse aggregates are firstly mixed with a half of water, then the cement and the rest of water are added) reduces the permeability, compared to the normal mixing [50].

\subsubsection{Conclusions on risks of steel corrosion}

The increase of the substitution ratio increases the porosity of RAC. The porosity accessible to water is an important indicator of the durability of RAC. However, this parameter is not enough for an assessment of the risks of steel corrosion. When a thorough investigation on the corrosion risk is required, it is more relevant to consider at least the chloride diffusion coefficient and the resistance to carbonation of RAC. The use of these two parameters takes already into account the porosity.

It is observed that the recycled aggregates decrease the performance of RAC (compared to natural aggregates), due to the porosity and the compacity of the cement paste in the new concrete. However, by optimizing the formulation (especially by reducing the water/binder ratio), although with high substitution ratio, one can obtain RAC with the resistances to carbonation and to chloride diffusion equivalent to that of ordinary concretes [105]. Corinaldesi \& Moriconithe (2009) [116] also showed that the addition of fly ash could be effective in reducing carbonation and chloride ion penetration depths in RAC.

\subsection{Resistance to thawing-freezing cycles}

Several studies noted that the thawing-freezing resistance of RAC is less than that of ordinary concrete [123], [124]. However, this resistance can be improved by using the pre-saturation of recycled aggregates (at $100 \%$ or $50 \%$ of saturation [125]); this result is explained by a possible internal curing of RAC. Kaihua et al. (2016)[126] showed that the thawing-freezing resistance 
of RAC closely depended on the properties of the parent concrete recycled. The use of airentrained can also increase the thawing-freezing resistance of RAC, equivalent to that of ordinary concretes [127].

\subsection{Alkali-silica reaction}

The alkali-silica reaction deteriorates the durability of concrete because it can provoke the cracking and the damages in the structure. The origin of the alkali-silica reaction is a chemical reaction between four components which must be simultaneously present in concrete: the reactive silica in the aggregates, a high concentration of alkaline, the presence of Portlandite, and a relative humidity $(\mathrm{RH})$ more than $70-80 \%$.

The recycled aggregate contains two very different phases: the cement paste bonded and the natural aggregates (sand and gravels). The cement paste contains the alkaline elements (generally in small amount). The aggregates have different natures, depending on their source; they can potentially contain the reactive phases. Therefore, the recycled aggregates can contain important quantities of soluble alkaline and potentially reactive silica. As the aggregates generally represents about $70 \%$ volume of concrete, the use of recycled aggregates presents a potential risk of alkali-silica reaction, especially the recycled fine aggregates which contains an important part of cement paste [105], [128], [129].

The alkali-silica reaction causes the expansion in concrete. Rougeau et al. (2018)[105] adopted the criterion of an acceptable expansion which was $0.02 \%$ after 5 months for RAC. The authors worked on aggregates at potentially reactive classes. The results show that the RAC with $100 \%$ of recycled coarse aggregate can satisfy the criterion of expansion. However, the limit of the recycle fine aggregate substituted is not more than $30 \%$ and an alkaline content less than 3 $\mathrm{kg} / \mathrm{m} 3$.

\subsection{Risk of ettringite and thaumasite formations}

One of problems relative to the use of recycled aggregates is the presence of pollutants which can be mortar, plaster, organic elements, chlorides, sulphates, glass, which can decrease the durability of RAC [7]. Several studies showed high contents of soluble sulphates in RAC [130], [131]. In the case of a very high soluble sulphate content, an internal sulphate attack can occur, leading to an adding expansion due to the formation of an important quantity of secondary ettringite [132]. This ettringite formation needs other specific simultaneous conditions: humid environment; presence of aluminates and alkaline possibly in the cement paste; high temperature of concrete at early age; etc. It is worth noting that on beside of ettringite, the thaumasite can be also created at the low temperature.

To reduce the risks related to the formations of ettringite or thaumasite due by the sulphate reactions, some authors proposed to limit the maximum content of acid-soluble sulphates for the recycled aggregates at $0.3 \%$, [105], while other references propose to limit at $0.8 \%$ [133].

\section{Reinforced RAC structures}

\subsection{Bonding between steel reinforcement rebars and RAC}

Among the first studies on the bonding of steel-concrete, Xiao \& Falkner (2007)[134] performed pull-out tests on RAC with two types of steel (smooth and ribbed). Different substitution levels of natural gravels by recycled coarse aggregates were chosen $(0 \%, 50 \%$ and $100 \%)$. The quantities of sand, cement and cement/water ratio were constant; so the compressive strength of RAC decreased when the substitution level increased, like other results presented in the previous sections. The results from the pull-out tests showed that when the coarse aggregate substitution increased, the bonding of smooth steel and RAC decreased, however, the bonding was constant for the case of ribbed steels. This result was confirmed later 
by numerous other studies which used the similar approach (fixing the binder amount constant)

648 and showed that there was not significant difference of bonding for the cases of ordinary 649 concretes and RAC [135]-[141].

650 Ghorbel et al. (2018)[142] used another approach by working on different ordinary concretes 651 and RAC (with different substitution levels) which had the same compressive strength. The authors carried out the pull-out tests and the four-points-bending tests. The results showed that although the tensile strength of RAC decreased slightly (less than 10\%, comparing to the reference ordinary concrete), there was no significant difference in the bonding strength between RAC and ordinary concretes. The authors also showed that the formula proposed in Eurocode 2 for the bonding strength of ordinary concretes could predict the bonding strength of RAC with satisfying accuracy (differences with the experimental results less than 10\%).

\subsection{Reinforced RAC columns}

Although the studies on RAC at the material scale is numerous, as cited in the previous sections, the researches at the structural scale of RAC structures (such as column, beam) are relatively recent and the number is limited. The investigations on the behaviour of reinforced RAC columns by Liu et al. (2010)[143], Zhou et al. (2010)[144], Choi \& Yun (2012)[145] can be cited. These studies concentrated on non-slender columns (slenderness from 4 to 9), with different substitution levels of natural gravels by recycled coarse recycled aggregates; the natural sand was not substituted. The columns were tested in compression with different eccentricities. The results showed that for ordinary concretes and RAC having the same compressive strengths, the behaviour of the columns was similar for the both cases.

Boissière et al. (2018)[146] tested also the non-slender column with RAC (slenderness of 8); however, for their RAC, the natural sand the natural gravels were both substituted by the recycled aggregates. The compressive strength was the same for all columns. The results showed that for the low substitution ratio (30\% gravel and 30\% sand; or 100\% gravels and $0 \%$ sand), the behaviour was quasi-identical for the columns in ordinary concretes and in RAC. However, for the total substitution of natural aggregates (100\% gravel and 100\% sand, especially for the case of $100 \%$ sand), the structure stiffness decreased significantly. This result is due to the decrease of the elastic modulus (already discussed in the sections 4.4.3) which increased the lateral deformations and the second-order moments. Therefore, the ultimate resistance of RAC columns in that case decreased slightly (about 10\%). The authors also showed that the calculation of the ultimate axial force following Eurocode 2 (EN 1992-1-1), with the adapted security coefficients, could be applied for non-slender reinforced RAC columns both for Ultimate Limit State (ULS) and Serviceability Limit State (SLS).

The most of studies in the literature indicate that the behaviour of non-slender columns in reinforced RAC can be considered the same as reinforced ordinary concrete, when the substitution ratio is not higher than 50\% [144], [146]. However, for slender columns, the differences are more significant because as mentioned earlier, RAC has lower elastic modulus and higher creep than ordinary concrete, which can increase the second-order moment (causing the buckling) and therefore reduce the ultimate capacity of slender reinforced RAC columns. However, the number of experiments on the slender columns in reinforced RAC is not available in the literature. Foure (2018)[147] carried out an analytical investigations on the slender columns in which the characteristics were adapted following the properties of RAC: the stressstrain relationship, the elastic modulus and the creep. The results showed that for short-term loadings (where the creep phenomenon has not yet occurred), when compared to the ordinary concrete columns, although the second-order moment increased significantly for RAC columns (about 30\%, due to a lower elastic modulus), the resistant ultimate axial force decreased slightly (about 10\%) which could be neglected in the structural design. However, for the long-term 
loadings (where the creep phenomenon is included), the decrease of the resistant force became non-neglected (about 25\%). Therefore, the author proposed that for the structural design of reinforced RAC structures, the creep phenomenon should be carefully taken into account, such as the coefficient $\mathrm{A}$ in the calculation of the limit slenderness (where $A=1 /\left(1+0.2 \varphi_{\text {ef }}\right)$; with $\varphi_{\text {ef }}$ is the creep coefficient).

\subsection{Reinforced RAC beams}

The beams are generally verified for the performances against bending moments, shear forces, deflections and cracking (opening and spacing). The number of studies on the behaviour of beams in reinforced RAC is still limited, however, several important results were reported in the existing studies. For the bending performance, Bai \& Sun (2010)[148] Ajdukiewicz \& Kliszczewicz (2007)[150], , Arezoumandi et al. (2015)[149], Knaack \& Kurama (2015)[150], Wardeh \& Ghorbel (2015)[151], Mercado-Mendoza et al. (2018)[152] showed that the ultimate bending resistance of the beams did not be affected by the substitution of natural aggregates by recycled aggregates; however, the deflections of beams in RAC increased when the substitution ratio increased, due to a lower elastic modulus of RAC than that of ordinary concrete.

For the deflection topic, Mercado-Mendoza et al. (2018)[152] showed that the calculations following Eurocode 2 could reproduce with satisfying accuracy the experimental deflections measured, which were at the short-term. To our knowledge, no study was experimentally investigated on the long-term deflections of reinforced RAC beams, but with a higher creep of RAC than ordinary concrete, it is expected that the long-term deflections of reinforced RAC beams would be more important. Therefore, the specifications in Eurocode 2 for the exemption of deflection calculations, which had been proposed for ordinary reinforced concretes, should be revised for reinforced RAC beams.

For the cracking of reinforced RAC beams, although Bai \& Sun (2010)[148] noted that the incorporation of recycled aggregates did not significantly modify the spacing between the cracks, other studies ([149], [151]-[153]) have shown that the crack spacing decreased when the substitution ratio of recycled aggregates increased. This result is due to the bondingstrength/tensile-strength which is slightly higher for RAC than that of ordinary concrete. Indeed, as presented in the sections 4.4.2 and 6.1, RAC has similar bonding strength but lower tensile strength than ordinary concrete [152]. The crack openings of RAC beams was also observed decreased when the substitution ratio increased. Mercado-Mendoza et al. (2018)[152] showed that when compared to the experimental results, the formulations in Eurocode 2 overestimated the crack openings and crack spacings. The reason was probably due to irrelevant parameters taken for RAC, such as the tensile strength.

The shear behaviour is a complex phenomenon, even for ordinary concretes. The shear performance of a reinforced concrete beam depends not only on the concrete properties, but also on the steel reinforcements (stirrups and longitudinal steels) and the beam geometry (especially the effective height). Therefore, to investigate the shear performance of reinforced RAC beams, certain authors choose to investigate the beams with or without stirrups [154][160]. The results showed that for a same compressive strength, the shear strength of RAC beams was slightly lower than that of ordinary concrete, but the mechanisms of failure (cracks) were the same. The decrease of shear strength in RAC beams is directly related to the lower tensile strength of this concrete when compared to ordinary concretes. The results also showed that the formula proposed in Eurocode 2 for ordinary concretes could predict the shear strength of RAC beams. The analyses at the macroscopic scale showed that while the shear failures in ordinary concrete beams occurred at the interfaces between the natural aggregates and the mortar, the shear failures in RAC beams occurred through the recycled aggregates [160]. 


\section{Fire behavior of RAC}

743 The number of studies investigating the performance of RAC at high temperature is still limited 744 [161], [162]. When the concrete is heated up, numerous phenomena appear, such as the dilatation of aggregates, the shrinkage of cement paste, the increase of vapor pressure, the cracking or the spalling. The RAC uses not only natural aggregates but also recycled aggregates which are more porous, have higher water absorption than natural aggregates, and contain also the hydrates (cement paste). Moreover, recycled aggregates possess two interfacial transition zones: the first one is between the mortar and the natural aggregates, the second one is between the new cement paste and recycled aggregates [163]. These transition zones are considered as the weak zones of mechanical properties [164], [165].

Like ordinary concretes, there are deteriorations in the mechanical properties when RAC is exposed to high temperature [166]-[170]. When there is no contaminants in recycled aggregates (wood, asphalt, etc.), the evolution of compressive strength of RAC in function of temperature is similar to ordinary concretes, however, the tensile strength of RAC decreases more rapidly. The non-cementitious contaminants had negative impacts on the residual mechanical properties of RAC, because when they are pyrolyzed, the cracking and porosity are created [171].

\subsection{Thermal conductivity and specific heat}

The conductivity and the specific heat are the thermo-physic parameters which have important influences on the fire behavior of RAC. To interpret different phenomena observed during the fire tests, these parameters must be investigated. Robert et al. (2018) [162] used the Transient Plane Source technique to measure these two parameters of different concretes: ordinary concrete with natural aggregates (0S0G), RAC in which $100 \%$ natural gravels were substituted by recycled coarse aggregates (0S100G), RAC in which $30 \%$ of natural sands and $30 \%$ of natural gravels were substituted by recycled fine and coarse aggregates, respectively (30S30G). These concretes have the same compressive strength grade $(\mathrm{C} 25 / 30)$. The measurements were performed on the cycles of heating-cooling. The results are illustrated on Figure 5 and Figure 6. From Figure 5, it is observed that at the ambient temperature, RAC have a lower thermal conductivity than the reference concrete. This difference comes from the higher porosity and the higher paste content in the RAC, as mentioned in the previous sections. The second observation is the thermal conductivity decreases when the temperature increases. This diminution of conductivity can be explained by the damage development in the concrete, because the residual strength of concretes having suffered thermal cycles is lower than that of unheated concretes. The potential mechanisms of damages are: the evaporation of water, because the thermal conductivity of water $(0.6 \mathrm{~W} /(\mathrm{m} . \mathrm{K}))$ is higher than that of air $(0.02$ $\mathrm{W} /(\mathrm{m} . \mathrm{K})$ ); the diminution of links due to the decomposition of hydrates; the microcracking from $300^{\circ} \mathrm{C}$. The conductivity of the reference concrete (0SOG) decreases more rapidly than that of RAC. This result is similar to other studies which showed that concretes having higher conductivity loss more quickly their conductivity with the increase of temperature [172]. Then, the differences of results between heating and cooling phases in the Figure 5 shows a hysteresis which confirms the irreversibility, especially that the concretes were really damaged [173]. 


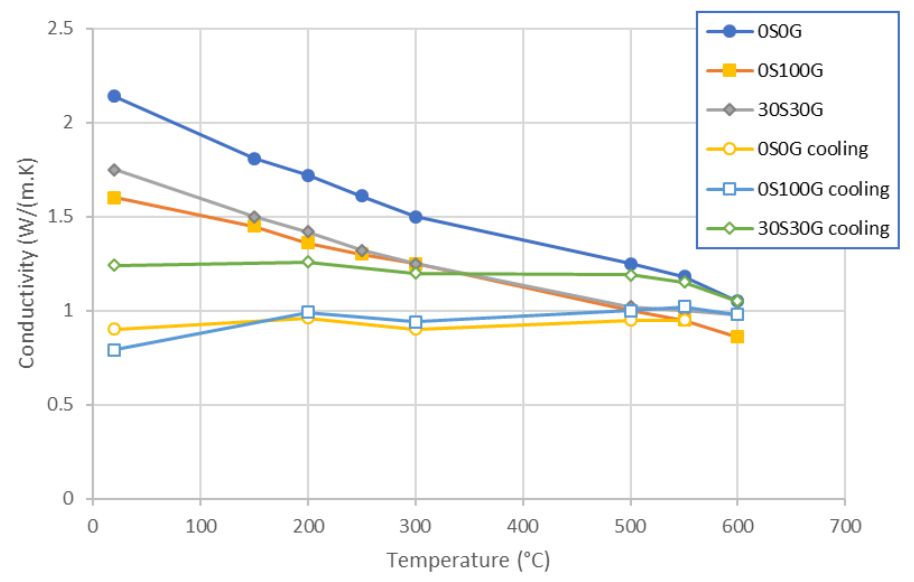

Figure 5. Evolution of thermal conductivity following the temperature, for the heating and cooling, obtained by Robert et al. (2018)[162].

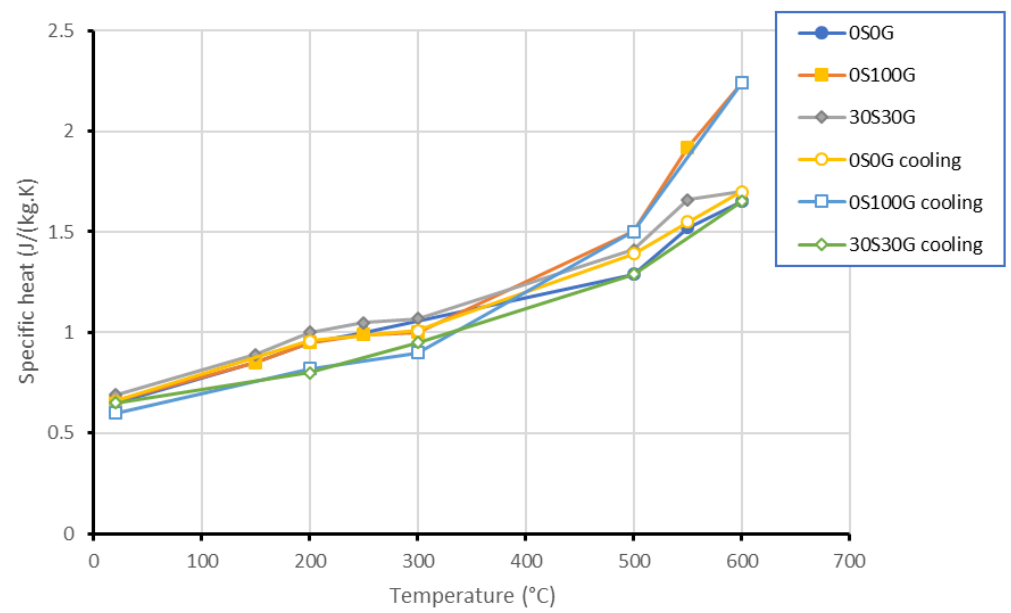

Figure 6. Evolution of specific heat following the temperature, for the heating and cooling, obtained by Robert et al. (2018)[162].

The results from Figure 6 show that the specific increases with the temperature increase; the recycled aggregates do not have significant influences on the specific heat, although some differences can be note between $500^{\circ} \mathrm{C}$ and $600^{\circ} \mathrm{C}$. In the case of specific heat, the hysteresis is significantly less remarked than that of the thermal conductivity. So, the increase of specific heat with the temperature is related to reversible phenomena. Indeed, the specific heat depends directly to the atomic vibrations, which is the principal mode of thermal energy absorption in the solids. When the temperature increases, the energy of atomic vibrations increases, which leads to a higher specific heat [162].

\subsection{Thermo-mechanical properties}

Robert et al. (2018) performed tests on specimens of 10-cm-diameter and 30-cm-height following recommendations TC 129-MHT of RILEM [174]. The concrete was of C35/45 grade. For each test, the specimen was preloaded at $20 \%$ of the compressive strength at the ambient temperature $\left(20^{\circ} \mathrm{C}\right)$, this preloading was kept constant during the heating test. Then, the temperature was increased $1{ }^{\circ} \mathrm{C} / \mathrm{min}$ until:

- $300^{\circ} \mathrm{C}$ then stabilized during 2 hours (for the tests at $300^{\circ} \mathrm{C}$ ), 
Two types of compression tests were performed: tested at high temperature and tested in residual state; for the second type, the specimens were let cooled down during $12 \mathrm{~h}$ after the stabilisation. The loading rate for the compression tests was $0.5 \mathrm{MPa} / \mathrm{second}$. The results obtained are presented in Figure 7, which shows the variation of the ratio between of the compressive strength at a temperature $\left(f_{c}(T)\right)$ on the compressive strength at the ambient temperature $\left(f_{c}\left(20^{\circ} \mathrm{C}\right)\right)$. Figure 7 illustrates the decrease of the compressive strength when the RAC was exposed to the high temperature. This result confirms the damages appeared when the concrete suffers to the high temperature, especially from $300^{\circ} \mathrm{C}$. The figure also shows that the analytical calculations following Eurocode 2-1-2 (discontinuous lines) provides the acceptable results comparing to the experimental ones, in particular for the case of silicate aggregates.

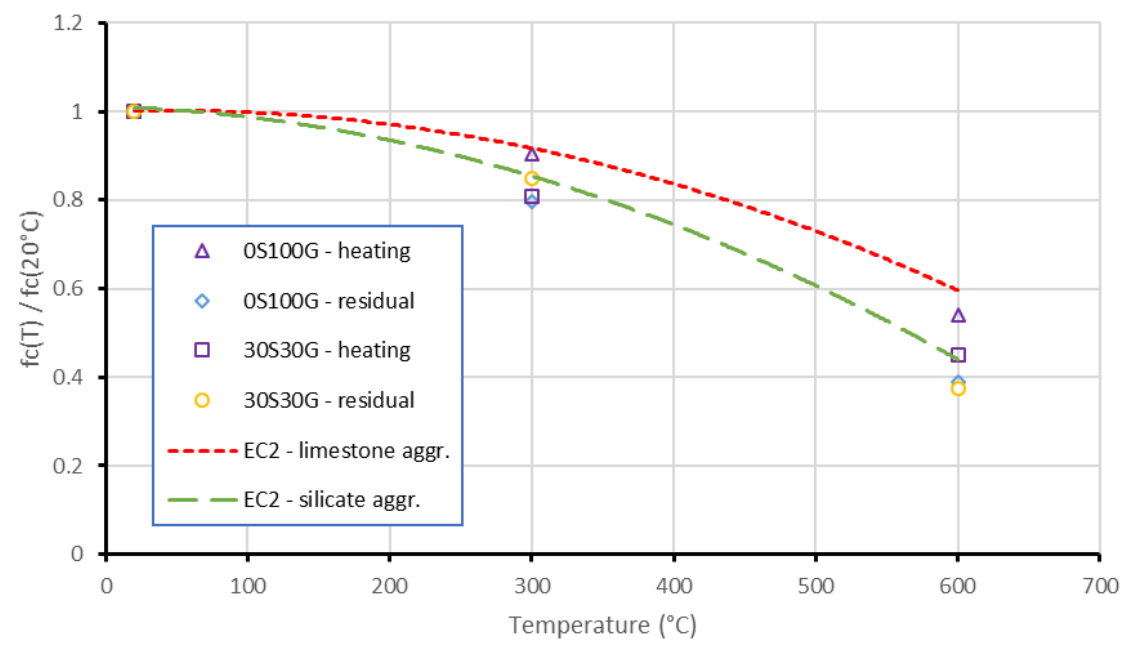

\section{Figure 7. The ratio $f_{c}(T) / f_{c}\left(20^{\circ} \mathrm{C}\right)$ in function of the temperature, obtained by experiments and following Eurocode 2. Source: Robert et al. (2018)[162].}

\subsection{Spalling tests and thermal profile}

Interesting spalling tests were presented by Robert et al. (2018): four slabs of 4.6-m-length $\times$ 1.5 -m-width $\times 0.2$-m-thickness were tested during 60 min following the standard EN 1363-1 (Figure 8). Two slabs were in ordinary concrete and two others are in RAC. The spalling was manually investigated (with a rule) after the tests, on the surface exposed to the fire. The results showed that the spalling on RAC slabs were slightly more remarked than that of ordinary concrete slab: about $1-3 \mathrm{~cm}$ of spalling-thickness for RAC slabs, compared to $0-2 \mathrm{~cm}$ for ordinary concrete slabs. However, the spalling on RAC slabs are local (about 10\% of the total surface), superficial and does not affect on the mechanical stability of the slabs. The higher water content of recycled aggregates may explain the reason of the higher spalling [162]. The results also showed that the application of a numerical code for the fire resistant design following Eurocode 2-1-2 could reproduce with satisfying accuracy the experimental behaviour obtained. 


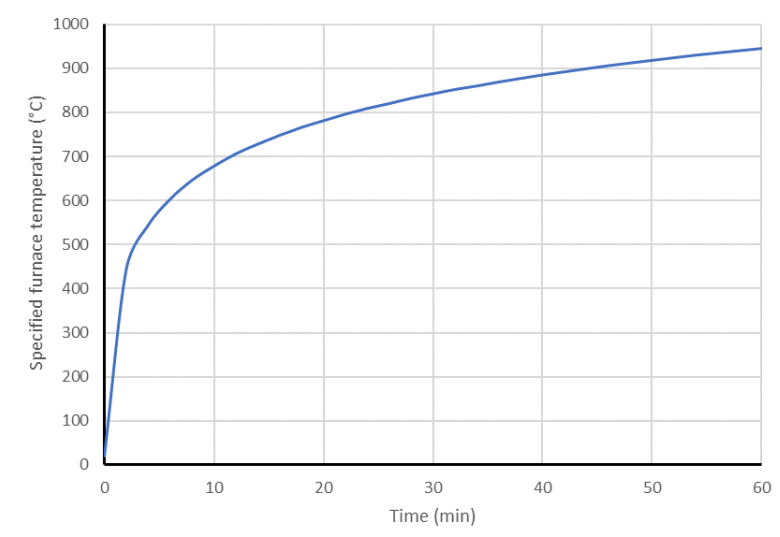

\section{Figure 8. Specified furnace temperature in function of time, following EN 1363-1.}

\subsection{Fire resistant tests}

The beams $(0.3-\mathrm{m} \times 0.4-\mathrm{m}$ of cross-section and 4.2-m-length) in reinforced RAC were tested in Robert et al. (2018)[162]. Two beams (0S100G and 30S30G) were tested in 3-point-bending test at ambient conditions; two others were tested also in 3-point-bending test but after a thermal treatment of 60 minutes, following EN 1363-1 (Figure 8). The results showed that for the beams tested at ambient conditions, the experimental results were slightly higher than the analytical calculations following Eurocode 2 (about 10\%). For the beams tested after the heating, the experimental results were significantly higher than that following Eurocode 2-1-2 for ordinary concretes (about 60\%). This result shows that reinforced RAC beams have good fire resistance, compared to ordinary concretes. However, this result should be confirmed with other types of recycled aggregates.

\section{Conclusion and prospect}

After considering different aspects relative to RAC, from the recycling of old-concreteaggregates, the mix proportioning, the mechanical properties, the durability, the structural behaviour and the fire resistance, it is observed that the application of RAC is not very complicated. The most important step is the recycling of old-concrete-aggregates. With recycled aggregates of relevant quality and with a reasonable substitution ratio of recycled aggregates, the RAC obtained possess the properties comparable to that of ordinary concretes with natural aggregate. The possible substitution ratio for coarse aggregates can reach $100 \%$ in many cases, while for fine aggregates, it is more reasonable to limit the substitution ratio at $30 \%$ to satisfy the demand of numerous different criteria, although in many cases, higher substitution ratio (such as $50 \%$ ) can be successfully applied.

Today, most of recycling processes provides the recycled aggregates which are still covered by old cement pastes and contaminants. To obtain a same grade of compressive strength, the incorporation of these recycled aggregates demands more cement and admixtures, this problem can strongly influence on the economic and environmental competitions of RAC when compared to ordinary concretes. Therefore, with the current recycling techniques, the reasonable substitution ratios are about 30-40\%, even for recycled coarse aggregates. It is worth noting that the recycled fine aggregates are less suitable for a high substitution ratio in concrete, but they can be used in the processing of cement production.

For the future of RAC industry, different tracks still need to be investigated and improved: 
- More efficient methods of aggregate recycling to provide recycled aggregates of better quality, the old-cement-paste should be separated from the recycled aggregates, the contaminants should be better eliminated.

- The new methods should be developed to incorporate the recycled fine aggregates with higher substitution rates.

873

874

875

876

877

878

879

880

\section{1}

882

- The use of cements of new generation which are "greener" than the current cement. The use of other alternative binders (such as geopolymer [175], [176]) for $\mathrm{RAC}$ to replace cement will be interesting to reduce the environmental impacts.

- The creep and the fatigue of RAC need more investigations (experimental and numerical). The experiments on the structural elements of reinforced RAC are interesting to be continued, especially on the complex domains such as the shear design, the punching behavior.

\section{Acknowledgement}

The author would like to thank the European Union's Horizon 2020 Research and Innovation Programme for the funding under grant agreement no. 777823. 


\section{References}

[1] De Larrard F., Colina H. (Dir.), Le béton recyclé. Marne-la-Vallée : Ifsttar, 2018. Ouvrages Scientifiques, OSI4, 792 p., ISBN 978_2_85782-747-4.

[2] Braymand S., Ferraille A., Serres N., Idir R., Analyse du cycle de vie du béton de GBR, in De Larrard F. \& Colina H. (Dir.), Le béton recyclé. Marne-la-Vallée :Ifsttar, (2018). Ouvrages Scientifiques, OSI4.

[3] Bui Q.B., Morel J.C., Tran V.H., Hans S., Oggero M., How to use in-situ soils as building materials, Procedia Engineering 145 (2016) 1119 - 1126

[4] Pacheco-Torgal F., Ding Y., Handbook of Recycled Concrete and Demolition Waste, 1st Edition, Woodhead Publishing, 2013, 672 p., ISBN: 9780857096821

[5] Tam V.W.Y., Soomro M., Evangelista A.C.J., A review of recycled aggregate in concrete applications (20002017), Construction and Building Materials 172 (2018) 272-292.

[6] Behera M., Bhattacharyya S.K., Minocha A.K., Deoliya R., Maiti S., Recycled aggregate from C\&D waste \& its use in concrete-A breakthrough towards sustainability in construction sector: a review, Constr. Build. Mater. 68 (2014) 501-516.

[7] Khalaf F.M., DeVenny A.S., Recycling of Demolished Masonry Rubble as Coarse Aggregate in Concrete: Review, ASCE Journal of Materials in Civil Engineering, 16, 331-340, 2004.

[8] Tam V.W.Y., Improving waste management plans in construction projects, Handbook of recycled concrete and demolition waste, Woodhead Publishing Limited, 2013

[9] Coelho A., de Brito J., Conventional demolition versus deconstruction techniques in managing construction and demolition waste (CDW), Handbook of recycled concrete and demolition waste, Woodhead Publishing Limited, 2013a.

[10] Brokk, A handbook of demolition with Brokk, SORD Industry, 2000, 28p.

[11] CEREMA, Valorisation des Graves de déconstruction, Guide Rhône-Alpes, d'utilisation en Travaux Publics, 24 p., 2014 (in French).

[12] Bovea M.D., Powell J.C, Developments in life cycle assessment applied to evaluate the environmental performance of construction and demolition wastes, Waste Management, 50, 151-172, 2016

[13] Coelho A., de Brito J., Economic viability analysis of a construction and demolition waste recycling plant in Portugal - part I: location, materials, technology and economic analysis, Journal of Cleaner Production, 39, 338-352, 2013b.

[14] Lotfi S., Deja J., Rem P., Mróz R., van Roekel E., van der Stelt H., Mechanical recycling of EOL concrete into high-grade aggregates, Resources, Conservation and Recycling, 87, 117-125, 2014

[15] Montero A., Tojo Y., Matsuo T., Matsut, T., Yamada M., Asakura H., Ono Y., Gypsum and organic matter distribution in a mixed construction and demolition waste sorting process and their possible removal from outputs, Journal of Hazardous Materials, 175, 747-753, 2010.

[16] Tsoumani A.A., Barkoula N.-M., Matikas T.E., Recycled aggregate as structural material, Waste Biomass Valor, 6, 883-890, 2015.

[17] Kim T.-H., A Study on Carbon Emission Impact Analysis of Concrete Mixing Recycled Aggregate, Journal of Korea Society of Waste Management, 31, 96-104, 2014.

[18] Tam V.W.Y., Economic comparison of concrete recycling: A case study approach, Resources, Conservation and Recycling, 52, 821-828, 2008.

[19] Petavratzi E., Kingman S.W., Lowndes I.S., Assessment of the dustiness and the dust liberation mechanisms of limestone quarry operations, Chemical Engineering and Processing: Process Intensification, 46, 1412-1423, 2007.

[20] Weimann K., Giese L.B., Mellmann G., Simon F.-G., Building materials from waste, Materials Transactions, 44, 1255-1258, 2003.

[21] Cazacliu B., Le Guen L., Hamard E., Roux S., Braymand S., Elaboration des granulats de béton recyclé, in De Larrard F. \& Colina H. (Dir.), Le béton recyclé. Marne-la-Vallée :Ifsttar, (2018). Ouvrages Scientifiques, OSI4.

[22] Cazacliu B., Sampaio C.H., Miltzarek G., Petter C., Le Guen L., Paranhos R., Huchet F., Kirchheim A.P., 2014, The potential of using air jigging to sort recycled aggregates, Journal of Cleaner Production, 66, 46-53, 2014.

[23] Paranhos R.S., Cazacliu B.G., Sampaio C.H., Petter C.O., Neto R.O., Huchet F., A sorting method to value recycled concrete, Journal of Cleaner Production 112, Part 4, 2249-2258, 2016.

[24] Koji S., The current state and future prospects of waste and recycling in Japan, In: Proceedings of the First International Conference on Sustainable Urbanization, Hong Kong, 837-845, 2010.

[25] Xing W., Pietersen H., Hendriks C., Rem P., Improve the quality of construction and demolition waste by separation techniques, in: Advances in Building Technology, Elsevier, Oxford, 1439-1446, 2002.

[26] Ulsen C., Kahn H., Hawlitschek G., Masini E.A., Angulo S.C., Separability studies of construction and demolition waste recycled sand, Waste Management 33, 656-662, 2013.

[27] Silva, R.V., de Brito, J., Dhir, R.K., Properties and composition of recycled aggregates from construction and demolition waste suitable for concrete production, Construction and Building Materials, 65, 201-217, 2014a.

[28] Rémond S., Mechling J.M., Garcia-Diaz E., Lavaud R., Trauchessec R., Cazacliu B., Caractérisation des granulats de béton recyclé, in de Larrard F. \& Colina H. (Dir.), Le béton recyclé. Marne-la-Vallée :Ifsttar, (2018). Ouvrages Scientifiques, OSI4.

[29] Evangelista L., de Brito J., Durability performance of concrete made with fine recycled concrete aggregates, Cement and Concrete Composites, 32, 9-14, 2010. 
Diliberto C., Barnes-Davin L., Izoret L., Lecomte A., Mechling J.M., Natin P., Béton recyclé utilise comme matière première alternative pour la fabrication du clinker portland, in de Larrard F. \& Colina H. (Dir.), Le béton recyclé. Marne-la-Vallée :Ifsttar, (2018). Ouvrages Scientifiques, OSI4.

[31] Cyr M., Diliberto C., Izoret L., Lecomte A., Béton recyclé utilise comme constituant du ciment ou comme ajout cimentaire au béton, in de Larrard F. \& Colina H. (Dir.), Le béton recyclé. Marne-la-Vallée :Ifsttar, (2018). Ouvrages Scientifiques, OSI4.

[32] Quattrone M., Cazacliu B., Angulo S.C., Hamard E., Cothenet A., Measuring the water absorption of recycled aggregates, what is the best practice for concrete production? Construction and Building Materials, 123, 690703, 2016

[33] Joseph M., Boehme L., Sierens Z., Vandewalle L., Water absorption variability of recycled concrete aggregates, Magazine of Concrete Research, 67, 592-597, 2015.

[34] Belin P., Habert G., Thiery M., Roussel N., Cement paste content and water absorption of recycled concrete coarse aggregates, Materials and Structures, 47, 1451-1465, 2014.

[35] González J.G., Robles D.R., Valdés A.J., Morán del Pozo, J.M. Romero, M.I.G., Influence of Moisture States of Recycled Coarse Aggregates on the Slump Test, Advances Materials Research, 742, 379-383, 2013.

[36] Hansen T.C., Recycled Aggregates and Recycled Aggregate Concrete: Second State-of- the-Art, Report 19451989, 1992.

[37] Poon C.S., Shui Z.H., Lam L., Fok H., Kou S.C., Influence of moisture states of natural and recycled aggregates on the properties of fresh and hardened concrete. Cement and Concretes Research, 34, 31-36, 2004.

[38] Kadri E.-H., Mouret M., Rogat D., Tahar Z.A. Effet des granulats de béton recyclé sur les propriétés du béton frais. in de Larrard F. \& Colina H. (Dir.), Le béton recyclé. Marne-la-Vallée :Ifsttar, (2018). Ouvrages Scientifiques, OSI4.

[39] Ji T., Chen C.-Y., Chen Y.-Y., Zhuang Y.-Z. Chen, J.-F., Lin, X., Effect of moisture state of recycled fine aggregate on the cracking resistibility of concrete, Construction and Building Materials, 44, 726-733, 2013.

[40] Mefteh H., Kebaïli O., Oucief H., Berredjem L., Arabi N., Influence of moisture conditioning of recycled aggregates on the properties of fresh and hardened concrete, Journal of cleaner production, 54, 282-288, 2013.

[41] Sánchez-Roldán Z., Martín-Morales M., Valverde-Palacios I., Valverde-Espinosa I., Zamorano M., Study of potential advantages of pre-soaking on the properties of pre-cast concrete made with recycled coarse aggregate, Materiales de Construcción 66, 2016.

[42] Kurowa R., Tsuji M., Sawamoto T., Tanaka Y, Effect of water condition in aggregate and mixing procedure under decreased pressure on compressive strength of recycled aggregate concrete, JCA Proceedings of Cement \& Concrete, 53, 535-542, 1999.

[43] Li W., Xiao J., Sun Z., Kawashima S., Shah S.P., Interfacial transition zones in recycled aggregate concrete with different mixing approaches, Construction and Building Materials, 35, 1045-1055, 2012.

[44] Otsuki N., Miyazato S., Yodsudjai W., Influence of recycled aggregate on interfacial transition zone, strength, chloride penetration and carbonation of concrete, Journal of materials in civil engineering, 15, 443-451, 2003.

[45] Poon C., Chan D., The use of recycled aggregate in concrete in Hong Kong, Resources, Conservation and Recycling, 50 (3), 293-305, 2007.

[46] Brand A. S., Roesler J. R., Salas A., Initial Moisture and Mixing Effects on Higher Quality Recycled Coarse Aggregate Concrete, Construction and Building Materials, 79, 83-89, 2015.

[47] Liu Y., Wang W., Chen Y.F., Ji H., Residual stress-strain relationship for thermal insulation concrete with recycled aggregate after high temperature exposure, Construction and Building Materials, 129, 37-47, 2016.

[48] Liang, Y., Ye, Z., Vernerey, F., Xi, Y., Development of Processing Methods to Improve Strength of Concrete with 100\% Recycled Coarse Aggregate, Journal of Materials in Civil Engineering, 27, 2015.

[49] Kong D., Lei T., Zheng J., Ma C., Jiang J., Jiang J., Effect and mechanism of surface-coating pozzolanic materials around aggregate on properties and ITZ microstructure of recycled aggregate concrete, Construction and Building Materials, 24, 701-708, 2010.

[50] Tam V. W. Y., Tam, C. M., Diversifying Two-Stage Mixing Approach (TSMA) for Recycled Aggregate Concrete : TSMA S and TSMA Sc., Construction and Building Materials, 122 (10), 2068-2077, 2008.

[51] Zhan B.J., Xuan D.X., Poon C.S., Enhancement of recycled aggregate properties by accelerated CO2 curing coupled with limewater soaking process, Cement and Concrete Composites 89 (2018) 230-237

[52] Slowik V., Schmidt M., Fritzsch R., Capillary Pressure in Fresh Cement-Based Materials and Identification of the Air Entry Value, Cement and Concrete Composite, 30 (7), 557-565, 2008.

[53] Slowik V., Ju J.W., Discrete Modeling of Plastic Cement Paste Subjected to Drying, Cement and Concrete Composite, 33 (9), 925-935, 2011.

[54] Souche J-C., Devillers P., Salgues M., Garcia-Diaz E., Influence of recycled coarse aggregates on permeability of fresh concrete, Cement and Concrete Composite, Volume 83, October 2017, Pages 394-404.

[55] Roziere E., Cortas R., Loukili A., Tensile behaviour of early age concrete: New methods of investigation, Cement and Concrete Composites, 55, 153- 161, 2015.

[56] Hammer TA., Fossa KT., Bjøntegaard Ø., Cracking tendency of HSC: tensile strength and self generated stress in the period of setting and early hardening, Materials and Structures, 40, 319-24, 2007.

[57] Roziere E., Bendimerad A.Z., Souche J-C., Devillers P., Salgues M., Loukili A., Garcia-Diaz E., Béton recyclé au jeune age, in de Larrard F. \& Colina H. (Dir.), Le béton recyclé. Marne-la-Vallée :Ifsttar, (2018). Ouvrages Scientifiques, OSI4.

[58] Maruyama I., Sato R., A Trial of Reducing Autogenous Shrinkage By Recycled Aggregate, In Proceedings of the Fourth International Research Seminar, Report TVBM-3126, Gaithersburg, Maryland, USA, 264-270, 2005. 
Nguyen T.D., Le Saout G., Devilllers P., Garcia-Diaz E., The effect of limestone aggregate porosity and saturation degree on the interfacial zone, 2th International Symposium on Cement-Based Materials For Nuclear Waste (NUWCEM 2014), Avignon, France, 2014. Zhao Z., Rémond S., Damidot D., Xu W. Influence of hardened cement paste content on the water absorption of fine recycled concrete aggregates, Journal of Sustainable Cement-Based Materials, 2013. Kjellsen K.O., Wallevik OH., Fjalberg L., Microstructure and microchemistry of the paste-aggregate interfacial transition zone of high-performance concrete, Advanced Cement Resarch, 10, 33-40, 1998 Olivier J.P., Maso J.C., Bourdette B., Interfacial transition zone in concrete, Advance Cement Based Material, 2, 30-38, 1995. mortar, Cement and Concrete Research, 35, 1368-1376, 2005. Wasserman R., Bentur A., Interfacial interactions in lightweight aggregate concretes and their influence on the concrete strength, Cement and Conrete Composite, 18, 67-76, 1996.

Tam V.W., Gao X., Tam C., Chan C. New approach in measuring water absorption of recycled aggregates, Construction and Building Materials, 22(3), 364-9, 2008.

Garcia-Diaz E., Djerbi A., Le Saout G., Microstructure du béton recyclé, in de Larrard F. \& Colina H. (Dir.), Le béton recyclé. Marne-la-Vallée :Ifsttar, (2018). Ouvrages Scientifiques, OSI4.

Silva R.V., de Brito J., Dhir R.K., The influence of the use of recycled aggregates on the compressive strength of concrete: a review, European Journal of Environmental and Civil Engineering, 19(7), 825-849, 2014

Sedran T., Durand C., de Larrard F., An example of UHPFRC recycling, "Designing and Building with UHPFRC: State of the Art and Development”, Chapter 44, ed. J. Resplendino, F. Toulemonde, November 2010 , Wiley-ISTE, 814 p., 2010.

Pepe M., Dias R., Filho T., Koenders E. A.B., Martinelli E., A novel mix design methodology for Recycled Aggregate Concrete, Construction and Building Materials 122 (2016) 362-372

Bairagi N.K., Vidyadhara H.S., Ravande K., Mix design procedure for recycled aggregate concrete, Constr. Build. Mater. 4 (4) (1990) 188-193.

González-Taboada I., González-Fonteboa B., Martínez-Abella F., Pérez-Ordóñez J.L., Prediction of the mechanical properties of structural recycled concrete using multivariable regression and genetic programming, Constr. Build. Mater. 106 (2016) 480-499.

Fathifazl G., Abbas A., Razaqpur A.G., Isgor O.B., Fournier B., Foo S., New mixture proportioning method for concrete made with coarse recycled concrete aggregate, J. Mater. Civ. Eng. 21 (10) (2009) 601-611.

Younis K.H., Pilakoutas K., Strength prediction model and methods for improving recycled aggregate concrete, Constr. Build. Mater. 49 (2013) 688-701.

Vincent Mathias \& François de Larrard (2002) Prévision des résistances en compression des bétons au laitier, Revue Française de Génie Civil, 6:4, 545-562

De Larrard F., Concrete Mixture-Proportioning: a scientific approach, Modern Concrete Technology, series No. 9, A. Bentur and S. Mindness editors, E \& FN SPON, ISBN 0-419-23500-0, 1999.

Ghorbel E., Sedran T., Wardeh G., Propriétés mécaniques instantanées, in de Larrard F. \& Colina H. (Dir.), Le béton recyclé. Marne-la-Vallée :Ifsttar, (2018). Ouvrages Scientifiques, OSI4

Andrade G. P., Polisseni G. C., Pepe M., Filho R. D. T., Design of structural concrete mixtures containing fine recycled concrete aggregate using packing model, Construction and Building Materials 252 (2020) 119091.

Dao D-T, Sedran T., de Larrard F., Optimization of the recycling of concrete in concrete: application to an airport slab, 12th international symposium on concrete road, Prague, Czech Republic, 23-26, 2014.

NF EN 1097-1, Essais pour déterminer les caractéristiques mécaniques et physiques des granulats - Partie 1 : détermination de la résistance à l'usure (micro-Deval), AFNOR, La Plaine Saint-Denis, 2011.

Ajdukiewicz A.B., Kliszczewicz A.-T., Comparative tests of beams and columns made of recycled aggregate concrete and natural aggregate concrete, Journal of Advances in Concrete Technology, 5, 259-273, 2007.

WRAP (Waste and Resources Action Programme), Aggregates Research Programme. Engineering properties of concrete containing recycled aggregates, Banbury (UK), 2007a.

Khoshkenari A. G., Shafigh P., Moghimi M., Bin Mahmud H., The role of 0-2 mm fine recycled concrete aggregate on the compressive and splitting tensile strengths of recycled concrete aggregate concrete, Materials and Design, 64, 345-354, 2014.

Omary S., Ghorbel E., Wardeh G., Relationships between recycled concrete aggregates characteristics and recycled aggregates concretes properties, Construction and Building Materials, 108, 163, 2016.

Wardeh G., Ghorbel E., Gomart H., Mix Design and Properties of Recycled Aggregate Concretes: Applicability of Eurocode 2, International Journal of Concrete Structures and Materials, 9(1), 1-20, 2015.

Xiao J.-Zh., Li J.-B., Zhang Ch., On relationships between the mechanical properties of recycled aggregate concrete: An overview, Materials and Structures, 39, 655-664, 2006.
Belén G-F., Martinez-Abella F., Carro Lopez D., Seara-Paz S., Stress-st for concrete using recycled saturated coarse aggregate, Construction and Building Materials, 25(5), 2335-2342, 2011.

Breccolotti M., D’Alessandro A., Roscini F., Bonfigli M.F., Investigation of stress - strain behaviour of recycled aggregate concrete under cyclic loads, Environmental Engineering and Management Journal, 14, 1543-1552, 2015.

Folino P., Xargay H., Recycled aggregate concrete - Mechanical behavior under uniaxial and triaxial compression, Construction and Building Materials, 56, 21-31, 2014. 
Eurocode 2, Eurocode 2 : calcul des structures en béton, Partie 1-1: Règles générales et règles pour le bâtiment, AFNOR, La Plaine Saint-Denis, 2005.

[90] Sagoe-Crentsil K. K., Brown T., Taylor A. H., Performance of Concrete Made with Commercially Produced Coarse Recycled Concrete Aggregate, Cement and Concrete Research, 31, 707-712, 2001.

[91] Gómez-Soberón J. M., Relationship between Gas Adsorption and the Shrinkage and Creep of Recycled Aggregate Concrete, Cement and Concrete Aggregates, 25, 42-48, 2003.

[92] Katz A., Properties of Concrete Made with Recycled Aggregate from Partially Hydrated Old Concrete, Cement and Concrete Research, 33, 703-711, 2003.

[93] Domingo-Cabo A., Lázaro C., López-Gayarre F., Serrano-López M. A., Serna P., Castaño-Tabares J. O., Creep and Shrinkage of Recycled Aggregate Concrete, Construction and Building Materials, 23 (7), 2545-2553, 2009.

[94] Fathifazl G., Ghani Razaqur A., Burkan Isgor O., Abbas A., Fournier B., Foo S., Creep and Drying Shrinkage Characteristics of Concrete Produced with Coarse Recycled Concrete Aggregate, Cement and Concrete Composite, 33 (10), 1026-1037, 2011.

[95] Manzi S., Mazzotti C., Bignozzi M. C., Short and Long-Term Behavior of Structural Concrete with Recycled Concrete Aggregate, Cement and Concrete Composites, 37, 312-318, 2013.

[96] Pedro D., de Brito J., Evangelista L., Influence of the Use of Recycled Concrete Aggregates from Different Sources on Structural Concrete, Construction and Building Materials, 71, 141-151, 2014.

[97] Grondin F., de Sa C., Sedran T., Cassagnabère F., Benboudjema F., Bendimerad A.Z., Guo M., Loukili A., Nicot P., Rozière E., Fouré B., Propriétés mécaniques différées, in de Larrard F. \& Colina H. (Dir.), Le béton recyclé. Marne-la-Vallée :Ifsttar, (2018). Ouvrages Scientifiques, OSI4.

[98] Gomez-Soberon J. M., Creep of Concrete with Substitution of Normal Aggregate by Recycled Concrete Aggregate, ACI Material Journal, 209, 461-474, 2002.

[99] WRAP (Waste and Resources Action Programme). An investigation into the effects of recycled aggregates on the engineering properties of concrete, 104, 2007b.

[100] Fan Y., Xiao J., Tam V. W., Effect of old attached mortar on the creep of recycled aggregate concrete, Structural Concrete, 15(2), 169-178, 2014.

[101] Arora S., Singh S. P., Flexural Fatigue Analysis of Concrete made with 100\% Recycled Concrete Aggregates, Journal of Materials and Engineering Structures, 2, 77-89, 2015.

[102] Xiao J., Li H., Yang Z., Fatigue behavior of recycled aggregate concrete under compression and bending cyclic loadings, Construction and Building Materials, 38, 681-688, 2013.

[103] Sobhan K., Gonzalez L., Reddy D. V., Durability of a pavement foundation made from recycled aggregate concrete subjected to cyclic wet-dry exposure and fatigue loading, Materials and Structures, 49, 2271-2284, 2016.

[104] Arora S., Singh S. P., Analysis of flexural fatigue failure of concrete made with 100\% Coarse Recycled Concrete Aggregates, Construction and Building Materials, 102, 782-791, 2016.

[105] Rougeau P., Schmitt L., Nai-Nhu J., Djerbi A., Sailio M., Ghorbel E., Mechling J.-M., Bulteel D., Cyr M., Lecomte A., Leklou N., Trauchessec R., Moulin I., Lenormand T., Amiri O., Propriétés liées à la durabilité, in de Larrard F. \& Colina H. (Dir.), Le béton recyclé. Marne-la-Vallée :Ifsttar, (2018). Ouvrages Scientifiques, OSI4

[106] Cui Z.L., Lu S.S., Wang Z.S., Influence of recycled aggregate on strength and preview the carbonation properties of recycled aggregate concrete, Journal of Buildings and Materials, 2004.

[107] Evangelista L., de Brito J., Durability performance of concrete made with fine recycled concrete aggregates, Cement and Concrete Composites, 32, 9-14, 2010.

[108] Sim J., Park C., Compressive strength and resistance to chloride ion penetration and carbonation of recycled aggregate concrete with varying amount of fly ash and fine recycled aggregate, Waste Manage (Oxford), 2011.

[109] Lotfi S., Eggimann M., Wagner E., Mroz R., Deja J., Performance of recycled aggregate concrete based on a 
Silva, R.V, Neves, R., de Brito, J, Dhir, R.K. Carbonation behaviour of recycled aggregate concrete, Cement and Concrete Composites, 62, 22-32, 2015b.

1131

1132

1133

1134

1135

1136

1137

1138

1139

1140

1141

1142

1143

1144

1145

1146

1147

1148

1149

1150

1151

1152

1153

1154

1155

1156

1157

1158

1159

1160

1161

1162

1163

1164

1165

1166

1167

1168

1169

1170

1171

1172

1173

1174

1175

1176

1177

1178

1179

1180

1181

1182

1183

1184

1185

1186

1187

1188

1189

1190

1191

Ryu J.S., An experimental study on the effect of recycled aggregate on concrete properties, Magazine of Concrete Research, 2002.

[112] Bravo M., de Brito J., Pontes J., Evangelista L., Durability performance of concrete with recycled aggregates from construction and demolition waste plants, Construction and Building Materials, 2015.

[113] Dhir R.K., Limbachiya M.C., Leelawat T., Suitability of recycled concrete aggregate for use in BS 5328 designated mixes, Institute of Civil Engineering - Structures Buildings, 1999.

[114] Amorim P., de Brito J., Evangelista L., Concrete made with coarse concrete aggregate: influence of curing on durability, ACI Materials Journal, 2012.

[115] Buyle-Bodin F., Hadjieva-Zaharieva R., Influence of industrially produced recycled aggregates on flow properties of concrete, Materials and Structures, 2002.

[116] Corinaldesi V, Moriconithe G., Influence of mineral additions on the performance of $100 \%$ recycled aggregate concrete Construction and Building Materials 23 (2009) 2869-2876.

[117] Sucic A., Lotfy A., Effect of new paste volume on performance of structural concrete using coarse and granular recycled concrete aggregate of controlled quality, Construction and Buildings Materials, 2016.

[118] Abbas A., Fathifazl G., Durability of recycled aggregate concrete designed with equivalent mortar volume method, Cement and Concrete Composites, 2009.

[119] Limbachiya M.C., Dhir R.K., Leelawat T., Use of recycled concrete aggregate in high-strength concrete, Materials and Structures, 33, 2000.

[120] Olorunsogo F.T., Padayachee N., Performance of recycled aggregate concrete monitored by durability indexes, Cement and Concrete Research, 32, 2002.

[121] Gonçalves A., Esteves A., Vieira M., Influence of recycled concrete aggregates on concrete durability, International RILEM Conference on the Use of Recycled Materials in Buildings and Structures, 2004.

[122] Kwan W.H., Ramli M., Kam K.J., Sulieman M.Z., Influence of the amount of recycled coarse aggregate in concrete design and durability properties, Construction and Buildings Materials, 26, 2012.

[123] Coquillat G., Recyclage de matériaux de démolition dans la confection de béton, CEPTB - Service d'Etude des matériaux, Unité : technologie des bétons, 80, 61-248, 1982.

[124] Zaharieva R., Buyle-Bodin F, Wirquin E., Frost resistance of recycled aggregate concrete, Cement and Concrete Research, 34, 2004.

[125] Yildrin S.T., Meyer C., Herfellner S., Effects of internal curing on strength, drying shrinkage and freeze-thaw resistance of concrete containing recycled concrete aggregates, Construction and Building Material, 91, 288296, 2015.

[126] Kaihua L., Jiachuan Y., Qiong H., Yao S., Chaoying Z., Effects of parent concrete and mixing method on the resistance to freezing and thawing of airentrained recycled aggregate concrete, Construction and Building Materials, 106, 264-273, 2016.

[127] Richardson A., Coventry K., Bacon J., Freeze/thaw durability of concrete with recycled demolition aggregate compared to virgin aggregate concrete, Journal of Cleaner Production, 19, 2011.

[128] Shehata M.H., Christidis C., Mikhaiel W., Rogers C., Lachemi M., Reactivity of reclaimed concrete aggregate produced from concrete affected by alkali-silica reaction, Cement and Concrete Research, 40, 575-582, 2010.

[129] Etxeberria M., The role and influence of recycled aggregate, Recycled Materials in Building and Structures, RILEM, Barcelona, Spain, 2004.

[130] Barbudo A., Galvín A.P., Agrela F., Ayuso J., Jiménez J.R., Correlation analysis between sulphate content and leaching of sulphates in recycled aggregates from construction and demolition wastes, Waste Management, 32, 6, 1229-1235, 2012.

[131] Tovar-Rodríguez G., Barra M., Pialarissi S., Aponte D., Vázquez E., Expansion of mortars with gypsum contaminated fine recycled aggregates, Construction and Building Materials, 38, 1211-1220, 2013.

[132] Neville A., The confused world of sulphate attack on concrete, Cement and Concrete Research, 34, 1275-1296, 2004.

[133] Mas B., Cladera A., del Olmo T., Pitarch F., Influence of the amount of mixed recycled aggregates on the properties of concrete for non-structural use, Construction and Building Materials 27 (2012) 612-622.

[134] Xiao J., Falkner H., Bond behaviour between recycled aggregate concrete and steel rebars, Construction and Building Materials, 21(2), 395-401, 2007.

[135] Butler L., West J.S., Tighe S.L., The effect of recycled concrete aggregate properties on the bond strength between RCA concrete and steel reinforcement, Cement and Concrete Research, 41(10), 1037-1049, 2011.

[136] Prince M. J. R., Singh B., Bond behaviour of deformed steel bars embedded in recycled aggregate concrete, Construction and Building Materials, 49, 852-862, 2013.

[137] Breccolotti M., Materazzi A. L., Structural reliability of bonding between steel rebars and recycled aggregate concrete, Construction and Building Materials, 47, 927-934, 2013.

[138] Kim S.-W., Yun H.-D., Influence of recycled coarse aggregates on the bond behavior of deformed bars in concrete, Engineering Structures, 48, 133-143, 2013.

[139] Kim S.-W., Yun H.-D., Evaluation of the bond behavior of steel reinforcing bars in recycled fine aggregate concrete, Cement and Concrete Composites, 46, 8-18, 2014.

1192

[140] Prince M. J. R., Singh B., Bond strength of deformed steel bars in high-strength recycled aggregate concrete, Materials and Structures, 48(12), 3913-3928, 2014. 
Guerra M., Ceia F., de Brito J., Julio E., Anchorage of steel rebars to recycled aggregates concrete, Construction and Building Materials, 72, 113-123, 2014

[142] Ghorbel E., Wardeh G., Fouré B., Adhérence entre armatures et béton de GBR, in de Larrard F. \& Colina H. (Dir.), Le béton recyclé. Marne-la-Vallée :Ifsttar, (2018). Ouvrages Scientifiques, OSI4

[143] Liu C.L., Bai G., Wang L., Quan Z., Experimental study on the compression behavior of recycled concrete columns, 2nd International Conference on Waste Engineering and Management - ICWEM, 2010.

[144] Zhou J.H., He H.J., Meng X.H., Huan S., Experimental study of recycled concrete columns under large eccentric compression, Proceedings of the 12th international conference on engineering, science, Construction, and operations in challenging, environments, 2010, Doi :10.1061/411096(336)54.

[145] Choi W.C., Yun H.D., Compressive behavior of reinforced concrete columns with recycled aggregate under uniaxial loading, Engineering Structures, 41, 285-293, 2012.

[146] Boissière R., Al-Mahmoud F., Hamaidia A., Fouré B., Pièces comprimées, a) Poteaux faiblement élancés, in de Larrard F. \& Colina H. (Dir.), Le béton recyclé. Marne-la-Vallée :Ifsttar, (2018). Ouvrages Scientifiques, OSI4 Fouré B., Pièces comprimées, b) Poteaux élancés, in de Larrard F. \& Colina H. (Dir.), Le béton recyclé. Marne-

[147] Fouré B., Pièces comprimées, b) Poteaux élancés, in de
la-Vallée :Ifsttar, (2018). Ouvrages Scientifiques, OSI4

[148] Bai W.-H., Sun B.-X., Experimental study on flexural behavior of recycled coarse aggregate concrete beam. Applied Mechanics and Materials, 29, 543-548, 2010.

[149] Arezoumandi M., Smith A., Volz J.-S., Khayat K.-H. An experimental study on shear strength of reinforced concrete beams with 100\% recycled concrete aggregate, Engineering structures, 88, 154-162, 2015.

1211

[150] Knaack A.-M., Kurama Y.-C., Behavior of reinforced concrete beams with recycled concrete coarse aggregates, Journal of Structural Engineering, 141, 2015.

[151] Wardeh G., Ghorbel E., Analyse du coefficient de ductilité en courbure des sections en béton armé incorporant des granulats recyclés, 9e colloque National AFPS, Marne-La-Vallée, France, 2015.

[152] Mercado-Mendoza H., Apedo K., Wolff P., Fouré B., Poutres soumises à la flexion, in de Larrard F. \& Colina H. (Dir.), Le béton recyclé. Marne-la-Vallée :Ifsttar, (2018). Ouvrages Scientifiques, OSI4

[153] Kang T. H-K, Kim W., Kwak Y-K, Hong S-G., Flexural Testing of Reinforced Concrete Beams with Recycled Concrete Aggregates, ACI Structural Journal, 111(3), 607-616, 2014.

[154] Etxeberria M., Mari A.R., Vasquez E., Recycled aggregate concrete as structural material, Materials and Structures, 40(5), 529-541, 2006.

[155] Gonzalez-Fonteboa B., Martinez-Abella F., Shear strength of recycled concrete beams, Construction and Building Materials, 21(4), 887-893, 2007.

[156] Fathifazl G., Razaqur A.G., Isgorc O. B., Abbasd A., Fournier B., Foof S., Shear capacity evaluation of steel reinforced recycled concrete (RRC) beams, Engineering Structures, 33(3), 1025-1033, 2011.

[157] Yun H.D., You Y.C., Lee D.H., Effects of replacement ratio of recycled coarse aggregates on the shear performance of reinforced concrete beams without shear reinforcement, LHI Journal, 2(4), 471-477, 2011.

[158] Schubert S., Hoffmann C., Leemann A., Moser K., Motavalli M., Recycled aggregate concrete: Experimental shear resistance of slabs without shear reinforcement, Engineering Structures, 41, 490-497, 2012.

[159] Arezoumandi M., Smith A., Volz J.-S., Khayat K.-H. An experimental study on shear strength of reinforced concrete beams with $100 \%$ recycled concrete aggregate, Engineering structures, 88, 154-162, 2015.

[160] Wardeh G., Ghorbel E., Fouré B., Poutres soumises à l'effort tranchant, in de Larrard F. \& Colina H. (Dir.), Le 
béton recyclé. Marne-la-Vallée :Ifsttar, (2018b). Ouvrages Scientifiques, OSI4

[161] Cree D., Green M.F., Noumowé A., Residual strength of concrete containing recycled materials after exposure to fire: a review, Construction and Building Materials, 45, 208-223, 2013.

[162] Robert F., Beaucourt A.L., Colina H., Comportement au feu, in de Larrard F. \& Colina H. (Dir.), Le béton recyclé. Marne-la-Vallée :Ifsttar, (2018). Ouvrages Scientifiques, OSI4

[163] Liu Q., Xiao J.Z., Sun Z.H., Experimental study on the failure mechanism of recycled concrete, Cement and Concrete Research, 41 (10), 1050-1057, 2011.

[164] Behera M., Bhattacharyya S.K., Minocha A.K., Deoliya R., Maiti S., Recycled aggregate from C\&D waste \& its use in concrete - a breakthrough towards sustainability in construction sector: A review, Construction and Building Materials, 68, 501-516, 2014

[165] Scrivener K.L., Crumbie A.K., Laugesen P., The Interfacial Transition Zone (ITZ) between cement past and aggregate in concrete, Interface Science, 12, 411-421, 2004.

[166] Zega CJ., Di Maio AA., Recycled concrete exposed to high temperatures, Magazine of Concrete Research, 58 (10), 675-682, 2006.

[167] Sarhat S. Sherwood E., Residual Mechanical Response of Recycled Aggregate Concrete after Exposure to Elevated Temperature, Journal of Material in Civil Engineering, 25, 1721-1730, 2013.

[168] Xiao J., Fan Y., Tawana M.M., Residual compressive and flexural strength of a recycled aggregate concrete following elevated temperatures, Berlin - Structural Concrete 14 (2), 2013b.

[169] Vieira JPB., Correia JR., Brito J., Post-fire residual mechanical properties of concrete made with recycled concrete coarse aggregates, Cement Concrete Research, 41, 533-541, 2011.

[170] Eguchi K., Teranishi K., Akira N., Hitoshi K., Kimihiko S., Masafumi N., Application of recycled coarse aggregate by mixture to concrete construction, Construction and Building Materials, 21, 1542-1551, 2007.

[171] Laneyrie C., Beaucour A-L., Green M., Hebert R., Ledesert B., Noumowé A., Influence of recycled coarse aggregates on normal and high performance concrete subjected to elevated temperatures, Construction and Building Materials, 111, 368-378, 2016.

[172] Xing Z., Beaucour A-L., Hebert R., Noumowe A., Ledesert B., Aggregate's influence on thermophysical concrete properties at elevated temperature, Construction and Building Materials, 95, 18-28, 2015.

[173] Yermak N., Pliya P., Beaucour A-L., Simon A., Noumowe A., Influence of steel and/or polypropylene fibres on the behaviour of concrete at high temperature: spalling, transfer and mechanical properties, Construction and Building Materials, 132, 2017.

[174] RILEM, Compressive strength for service and accident conditions, RILEM Draft Recommendation 129-MHT Test Methods for Mechanical Properties of Concrete at High Temperatures, Materials and Structures, 28, 7 , 410-414, 1995.

[175] Davidovits J., Global warming impact on the cement and aggregates industries, World Resour. Rev., 6, 2, 263278, 1994.

[176] Ren X., Zhang L., Experimental Study of Geopolymer Concrete Produced from Waste Concrete, Journal of Materials in Civil Engineering, Volume 31 Issue 7 - July 2019. 